\title{
Hydrous Na-garnet from Garnet Ridge; products of mantle metasomatism underneath the Colorado Plateau
}

\author{
Kunihiko Sakamaki ${ }^{*}$ Y Yuto Sato and Yoshihide Ogasawara
}

\begin{abstract}
This is the first report on amphibole exsolution in pyrope from the Colorado Plateau. Pyrope crystals delivered from mantle depths underneath the Colorado Plateau by kimberlitic volcanism at $30 \mathrm{Ma}$ were collected at Garnet Ridge, northern Arizona. The garnet grains analyzed in this study occur as discrete crystals (without adjacent rock matrix) and are classified into two major groups, Cr-rich pyrope and Cr-poor pyrope. The Cr-poor pyrope group is divided into four subgroups based on exsolved phases: amphibole lamella type, ilmenite lamella type, dense lamellae type, and clinopyroxene/amphibole lamellae type. Exsolved amphibole occurs in amphibole lamella type, dense lamellae type, and clinopyroxene/amphibole lamellae type of Cr-poor pyrope. The amphibole crystals tend to have preferred orientations in their garnet hosts and occur as monomineralic hexagonal or rhombic prisms and tablets, and as multimineralic needles or blades with other exsolved phases. Exsolved amphibole has pargasitic compositions $\left(\mathrm{Na}_{2} \mathrm{O}\right.$ up to 1.6 apfu based on 23 oxygen). Garnet host crystals that have undergone amphibole exsolution have low $\mathrm{OH}$ contents (2-42 ppmw $\mathrm{H}_{2} \mathrm{O}$ ) compared to garnets that do not have amphibole lamellae (up to 115 ppmw $\mathrm{H}_{2} \mathrm{O}$ ). The low $\mathrm{OH}$ contents of garnets hosting amphibole lamellae suggest loss of $\mathrm{OH}$ from garnet during amphibole exsolution. Amphibole exsolution from pyrope resulted from breakdown of a precursor "hydrous Na-garnet" composition $\left(\mathrm{Mg}_{1} \mathrm{Na}_{x}^{+}\right)_{3}\left(\mathrm{Al}_{2-x}, \mathrm{Mg}_{x}\right)_{2} \mathrm{Si}_{3} \mathrm{O}_{12-2 x}(\mathrm{OH})_{2 x}$. Exsolution of amphibole and other phases probably occurred during exhumation to depths shallower than $100 \mathrm{~km}$ prior to volcanic eruption.

Based on the abundance and composition of exsolved clinopyroxene and amphibole lamellae in one garnet, hydrous Na-garnet had excess silicon ( $\mathrm{Si}_{3.017}$ apfu, 12 oxygen normalization, vs. $\mathrm{X}_{3} \mathrm{Y}_{2} \mathrm{Si}_{3} \mathrm{O}_{12}$ for typical garnet). Comparison with experimental data suggests crystallization at pressures near 6-8 GPa. Garnet crystals that host exsolved amphibole have compositions ( $\mathrm{Pyp}_{49-76}, 3-10 \mathrm{wt} \% \mathrm{CaO}$, and up to $0.6 \mathrm{wt} \% \mathrm{Cr}_{2} \mathrm{O}_{3}$ ) similar to garnets reported from pyroxenites, and have pyrope-almandine-grossular compositional ranges that overlap with the Cr-rich pyrope (typical Iherzolitic garnet).

Hydrous Na-garnet was likely formed by metasomatic reactions between $\mathrm{Cr}$-rich pyrope and Na-rich aqueous fluid in the deep upper mantle. The most likely source of metasomatic Na-rich fluid is ancient oceanic crust that was subducted before subduction of the Farallon Plate beneath the Colorado Plateau.
\end{abstract}

Keywords: Hydrous Na-garnet, The Colorado Plateau, Amphibole exsolution, Pyrope, Mantle metasomatism

\footnotetext{
* Correspondence: k.sakamaki@akane.waseda.jp

Department of Earth Sciences, Waseda University, 1-6-1 Nishiwaseda,

Shinjuku-ku, Tokyo 169-8050, Japan
} 


\section{Background}

Various garnet crystals and garnet-bearing xenoliths occur at Garnet Ridge, northern Arizona, USA (Switzer 1975). These garnets were delivered to the surface from a wide range of depths from the deep mantle to crustal levels underneath the Colorado Plateau by a kimberlitic diatreme associated with the Navajo volcanic field during Oligocene time (e.g., Watson and Morton 1969). The kimberlitic diatreme at Garnet Ridge has been studied by many researchers (e.g., Gregory 1916; Switzer 1975; Wang et al. 1999; Smith et al. 2004), in part, because pyrope crystals carried by the diatreme have origins of great depths from the upper mantle. These pyrope crystals have wide chemical variations and various inclusions/exsolved phases such as silicates, sulfides, oxides, titanates, fluid/ melt, and composite grains of these phases (e.g., Wang et al. 1999, 2000; Sato and Ogasawara 2013, Sato et al. 2014). The variations of chemistry, inclusion phases, and exsolved phases suggest heterogeneities in the shallow to deep mantle underneath the Colorado Plateau.

We discovered exsolved amphibole in some of pyrope crystals from Garnet Ridge; this paper is the first report on exsolution lamellae of $\mathrm{Na}$-bearing amphibole in pyrope from the Colorado Plateau. Exsolution of Na-bearing amphibole from pyrope indicates that $\mathrm{Na}$ and $\mathrm{OH}$ components were enriched in garnet prior to exsolution (Song et al. 2005). At present, reports on Na-rich ( $>1 \mathrm{wt} \% \mathrm{Na}_{2} \mathrm{O}$ ) garnet are limited to inclusions in diamond from kimberlite pipes in South Africa and other localities (e.g., Moore and Gurney 1985; Sautter et al. 1991). Significant amounts of $\mathrm{Na}$ in garnet are evidence of ultrahigh pressure (UHP) conditions (Sobolev and Lavrent'ev. 1971; Bishop et al. 1978). Except for hydrogrossular-andradite, garnet that forms at low pressure is a nominally anhydrous mineral, but $\mathrm{OH}$ has been identified in garnet of mantle origin at concentrations ranging up to hundreds of ppmw (ppm wt\% as $\mathrm{H}_{2} \mathrm{O}$ ) (Aines and Rossman 1984; Ogasawara et al. 2012, 2013). Significant amounts of $\mathrm{OH}$ in pyrope-rich garnet are regarded as evidence of $\mathrm{H}_{2} \mathrm{O}$-rich environments at UHP conditions (Withers et al. 1998; Mookherjee and Karato 2010). In this study, we describe pyrope garnet with exsolution lamellae of Na-rich amphibole, indicating formation from a precursor $\mathrm{Na}$ and $\mathrm{OH}$ bearing garnet, namely hydrous Na-rich garnet. We argue that the hydrous Na-rich garnet formed by interactions between mantle peridotite and fluid originating from ancient subducted oceanic crust underneath the Colorado Plateau, and that exsolution of amphibole occurred by decompression during transit to the surface.

\section{Methods}

\section{Experimental samples from Garnet Ridge}

Garnet Ridge is a northeast-southwest trending ridge composed of the Jurassic Summerville Formation and
Bluff sandstone in northern Arizona in the central part of the Navajo volcanic field (Switzer 1975). The Navajo volcanic field is characterized by mid-Tertiary volcanic necks, dikes, lavas, and various intrusions of alkali-rich mafic and ultramafic rocks (Roden et al. 1979; Semken 2003). A xenolith-rich kimberlitic diatreme associated with the Navajo volcanisms erupted through Garnet Ridge at ca. $30 \mathrm{Ma}$ (Smith et al. 2004). Discrete garnet crystals (without surrounding rock matrix), garnet megacrysts, garnet aggregates, and garnet-bearing xenoliths (e.g., lawsonite-eclogite) are scattered on the ridge and the ground of the Carmel Formation and the Entrada sandstone surrounding Garnet Ridge (Watson and Morton 1969; Helmstaedt and Schulze 1988; Usui et al. 2003, 2006, 2007). This study is based on analyses of the discrete garnet crystals.

\section{Analytical methods}

Fine-grained inclusion phases were identified by spot analyses and 2D mapping with a laser Raman spectrometer, Horiba Jobin Yvon LabRAM300, at room temperature using a 514.5-nm Ar-ion laser and a 488-nm solid state laser as excitation lines. Unpolarized Raman signals were collected with an MPlan $\times 100$ microscope objective lens (Olympus Co., Tokyo, Japan) with $10 \mathrm{~mW}$ power for the Ar-ion laser and $25 \mathrm{~mW}$ power for the solid state laser and spot size of ca. $1 \mu \mathrm{m}$. The analytical resolution of the Raman spectra is accurate to $\pm<1 \mathrm{~cm}^{-1}$ wavenumbers as calibrated using a Si crystal as a standard.

Elemental compositions and 2D distributions of compositions in host garnet and guest phases were analyzed using an electron microprobe, JXA-8900 (JEOL Ltd., Tokyo, Japan), by electron microprobe wavelength dispersive spectroscopy (EMP-WDS) at Waseda University. Quantitative analyses were conducted using a $\mathrm{LaB}_{6}$ filament under the following conditions: accelerating voltage, 15 or $20 \mathrm{kV}$; beam current, $20 \mathrm{nA}$; and and beam diameter, $10 \mu \mathrm{m}$. For 2D elemental X-ray mapping, an accelerating voltage of $15 \mathrm{kV}$, a beam current of $200 \mathrm{nA}$, and a beam diameter of $1 \mu \mathrm{m}$ were used.

Water contents in garnet crystals were determined using a micro-Fourier transform infrared (micro-FTIR) spectrometer (Thermo Nicolet, Avatar 370 with Continuum) at Waseda University. In order to obtain highquality transmission IR spectra, the garnet samples were prepared as double-side polished sections (thickness: ca. 250-500 $\mu \mathrm{m})$. Measurements were conducted with an aperture size of $100 \times 100 \mu \mathrm{m}$ and a spectral resolution of $8 \mathrm{~cm}^{-1}$ using unpolarized light. Each spectrum was accumulated from 200 iterations on the same spot and was calibrated using polystyrene film as a standard. Peak fitting of IR spectra was conducted by the curve fitting method of the Lorentzian-Gaussian function in order to determine values of peak position, intensity, and full 
width at half maximum (FWHM) were determined for IR absorption bands caused by $\mathrm{OH}$ using the LabSpec 4.10 software associated with the Raman spectrometer. We estimate $\mathrm{OH}$ concentrations in host garnet using the Beer-Lambert law:

$$
C=18,000 \times I / d / \varepsilon / \rho
$$

where $C$ = water concentration $\left(\mathrm{OH}\right.$ as $\mathrm{H}_{2} \mathrm{O}$, ppmw.), $I=$ integrated IR absorption intensity, $d=$ sample thickness $(\mathrm{cm}), \varepsilon=\mathrm{IR}$ absorption coefficient $\left(\mathrm{L} / \mathrm{mol} / \mathrm{cm}^{2}\right)$ of water $(\mathrm{OH})$ in garnet, and $\rho=$ density of garnet. The absorption intensity $I$ is the integrated intensity of an IR absorption band caused by $\mathrm{OH}$ in garnet in the wavenumber range of $3400-3700 \mathrm{~cm}^{-1}$. We used an IR absorption coefficient of $8770 \mathrm{~L} / \mathrm{mol} / \mathrm{cm}^{2}$ presented by Katayama et al. (2006) and a density of pyrope of $3.58 \mathrm{~g} / \mathrm{cm}^{3}$ after Deer et al. (1992). Using the uncertainty in $I$ of $510 \mathrm{~L} / \mathrm{mol} / \mathrm{cm}^{2}$ reported by Katayama et al. (2006) and estimates of errors in sample thickness, peak fitting, and sample density, we use Gaussian error propagation to calculate relative uncertainties $(1 \sigma)$ in $\mathrm{OH}$ contents ranging from $8 \%$ for good conditions (water-rich, thick sample, well-defined baseline) to $14 \%$ for poor conditions (water-poor, thin sample, poorly defined baseline).

A key problem in this study is distinguishing phases that exsolved from garnet versus phases that were overgrown and trapped by garnet (trapped inclusions). We combined microscopic observations, phase mapping by laser Raman spectroscopy, and element mapping by
EMP-WDS and used the following criteria to identify exsolved phases: (1) preferred orientation of guest grains indicating a crystallographic relationship between guest grains and host garnet; (2) presence of guest grains in several garnet host crystals of the same type (see below); (3) homogeneous distributions of guest grains in certain areas of garnet host; (4) elemental depletion halos in host garnet around grains (e.g., Ti-poor halo in garnet around Ti-bearing amphibole grain); and (5) a high number of guest grains occurring within garnet host. We regarded inclusion phases satisfying at least three among these five conditions as exsolved phases (i.e., not trapped inclusions) in the strict sense.

\section{Results}

\section{Pyrope crystals from Garnet Ridge}

Pyrope crystals and their fragments occur as grains approximately 5-25 $\mathrm{mm}$ across with red, reddish-brown, purplish, and black colors. We classified pyrope crystals into two major groups (A and $\mathrm{B}$ ) on the basis of major element chemical compositions: group $\mathrm{A}$ is $\mathrm{Cr}$-rich with a limited range of pyrope-content and group $\mathrm{B}$ is $\mathrm{Cr}$ poor with more variable pyrope-contents (Table 1).

\section{Group A: Cr-rich pyrope}

Cr-rich pyrope looks reddish or purplish-colored by the naked eye (Fig. 1). Individual grains are chemically homogeneous based on microprobe analyses. From grain to grain, chemical compositions show the following ranges: Prp 67-74, Alm 13-18, and Grs 7-11 mol\%

Table 1 Classification of garnet on the basis of chemistry and inclusion/lamella phases

\begin{tabular}{|c|c|c|c|c|c|c|c|c|c|c|c|c|c|c|}
\hline \multirow[b]{2}{*}{ Garnet group } & \multirow[b]{2}{*}{ Color } & \multicolumn{4}{|l|}{ Chemistry } & \multicolumn{9}{|c|}{ Exsolution lamella phases } \\
\hline & & $\operatorname{Prp}_{(\mathrm{mol} \%)}$ & Alm (mol\%) & $\operatorname{Grs}_{(\mathrm{mol} \%)}$ & $\mathrm{Cr} 2 \mathrm{O} 3$ (wt.\%) & Cpx & Amp & Ap & Rt & $\mathrm{Ilm}$ & Ctn & Sri & $\mathrm{Crm}$ & Cr-Spl \\
\hline A. Cr-rich pyrope & Red-purple & $67-74$ & $13-18$ & $7-11$ & $1.0-6.4$ & & & & + & + & + & + & + & + \\
\hline \multicolumn{15}{|l|}{ B. Cr-poor pyrope } \\
\hline$B_{1}$. Amp type & Brown & $49-66$ & $18-28$ & $16-26$ & $<0.4$ & & ++ & + & ++ & ++ & + & + & & \\
\hline$B_{2}$. Ilm-only type & R-brown & $49-68$ & $20-38$ & $12-19$ & $0.4-2.0$ & & & & & ++ & & & & + \\
\hline$B_{3}$. Dense lamellae type & Black & $54-72$ & $18-33$ & $12-15$ & $<1.0$ & ++ & ++ & + & ++ & ++ & & + & & \\
\hline \multirow[t]{2}{*}{ B. Cpx-Amp type } & Light brown & $61-76$ & $13-27$ & $6-11$ & $<0.6$ & ++ & + & & ++ & ++ & & & & \\
\hline & \multicolumn{14}{|c|}{ Inclusions without lamella textures } \\
\hline Garnet group & $\mathrm{Ol}$ & Opx & Cpx & Ti-Chu & Chl & Spl & Crn & Dol & Mgs & Ap & sulfides & Multi & & \\
\hline A. Cr-rich pyrope & ++ & ++ & ++ & + & + & + & & & & & + & $+^{a}$ & & \\
\hline \multicolumn{15}{|l|}{ B. Cr-poor pyrope } \\
\hline$B_{1}$. Amp type & & & ++ & & + & & & + & + & + & + & & & \\
\hline $\mathrm{B}_{2}$. Ilm-only type & ++ & ++ & ++ & & + & & & & & + & + & $++^{b}$ & & \\
\hline$B_{3}$. Dense lamellae type & & & ++ & & & + & + & & & + & + & $++^{c}$ & & \\
\hline B4. Cpx-Amp type & + & + & & & & & & & & & + & & & \\
\hline
\end{tabular}

Ap apatite, Ctn crichtonite, Sri srilankite, $\mathrm{Crn}$ carmichaelite, $\mathrm{Cr}$-Spl chromian spinel, Ti-Chu titanian clinohumite, Crn corundum, Dol dolomite, Mgs magnesite

${ }^{a}$ Multi phase inclusions composed of Dol, Mgs, Amp, Phl, Rt, Ap, Cr-Spl, and sulfides

${ }^{\mathrm{b}}$ Multi phase inclusion composed of gas, liquid- $\mathrm{H} 2 \mathrm{O}$, and solid phases (rutile, chlorite, calcite, and barite)

${ }^{c}$ Multi phase inclusion composed of Dol, Mgs, Amp, Cpx, Opx, Ab, Ap, Rt, Ilm, and sulfides 

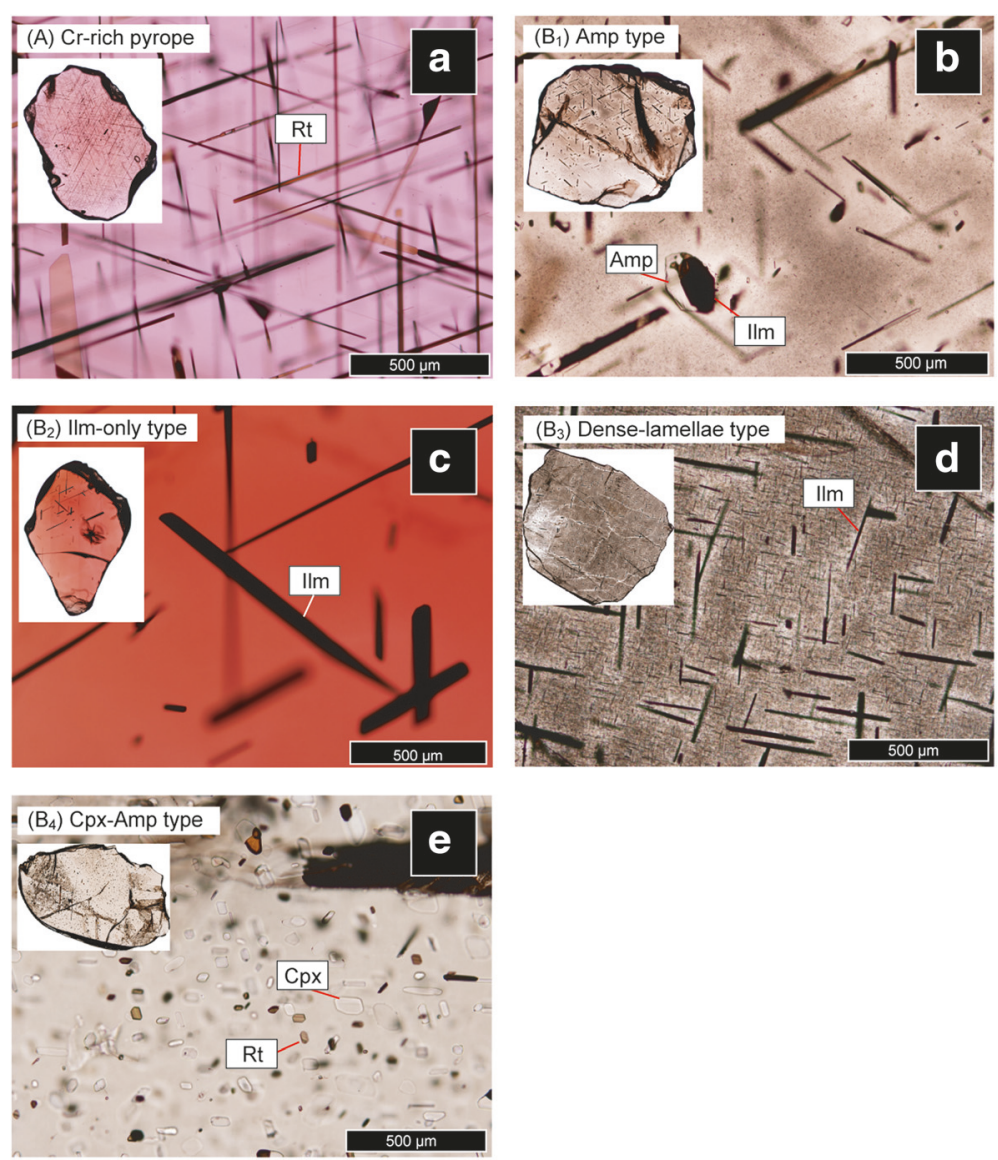

Fig. 1 Photomicrographs of group A, Cr-rich pyrope garnet and four subgroups of group B, Cr-poor pyrope. a Group A: Cr-rich pyrope. b $B_{1}$ : amphibole lamella type. c $B_{2}$ : ilmenite lamella type. d $B_{3}$ : dense lamellae type. e $B_{4}$ : clinopyroxene and amphibole lamellae type

(Fig. 2). The concentrations of $\mathrm{Cr}_{2} \mathrm{O}_{3}$ range from 1.0 up to $6.4 \mathrm{wt} \%$. The purplish color of group $\mathrm{A}$ garnet becomes darker with increasing $\mathrm{Cr}_{2} \mathrm{O}_{3}$. This garnet contains exsolution lamellae of anhydrous minerals such as rutile, ilmenite, crichtonite $\left[(\mathrm{Sr}, \mathrm{Ca}, \mathrm{K}, \mathrm{Na})\left(\mathrm{Cr}, \mathrm{Fe}^{2+}\right.\right.$, $\left.\left.\mathrm{Fe}^{3+}, \mathrm{Ti}, \mathrm{V}^{3+}, \mathrm{Zr}, \mathrm{Mg}\right)_{21}(\mathrm{O}, \mathrm{OH})_{38}\right]$, carmichaelite, [(Ti,Cr,Fe) $\mathrm{O}_{2-\mathrm{x}}(\mathrm{OH})_{\mathrm{x}}$, and Cr-spinel (Fig. 1 and Table 1). Inclusions of olivine, clinopyroxene, and orthopyroxene were recognized (Table 1). Spherical multiphase inclusions of dolomite, magnesite, amphibole, phlogopite, rutile, apatite, and $\mathrm{Cr}$-spinel are also present.

\section{Group B: Cr-poor pyrope}

Group B pyrope crystals are Cr-poor $\left(<2\right.$ wt $\left.\% \mathrm{Cr}_{2} \mathrm{O}_{3}\right)$ and show chemical variations in pyrope $(49-76 \mathrm{~mol} \%)$, almandine (13-38 mol\%), and grossular (6-26 mol\%) components (Figs. 1 and 2). Some group B garnets have $\mathrm{Mg}-\mathrm{Fe}-\mathrm{Ca}$ contents that overlap with group A garnet, but group $B$ shows a wider chemical range to more Ca- and/or Fe-rich compositions (Fig. 2).

The garnets of group B are subdivided into four subgroups based primarily on the identities and abundances of exsolved phases (Tables 1 and 2; Fig. 1). All of the subgroups contain exsolution lamellae of ilmenite, but other exsolved phases vary. Exsolved phases, along with host garnet chemical compositions and colors of the subgroups are described below.

Subgroup $B_{1}$, amphibole lamella type (Prp 49-66; Alm 18-28; Grs 16-26 mol\%), occurs as reddishbrown-colored pyrope crystals. Subgroup $B_{1}$ contains exsolved lamellae of amphibole, rutile, ilmenite, and minor mounts of srilankite $\left[(\mathrm{Ti}, \mathrm{Zr}) \mathrm{O}_{2}\right]$, apatite, and crichtonite. These exsolved phases occur as needles (up to $1 \mathrm{~mm}$ in long dimension) consisting of multiple minerals ranging from 20 to $300 \mu \mathrm{m}$ in length throughout each garnet host crystal. Coarse-grained exsolved minerals are typically surrounded by depletion halos of several to tens of micrometers in width, where fine-grained exsolved phases are absent (Fig. 1). A few chlorite inclusions were identified; they are a primary mineral of hydrated mantle and were trapped during growth of host garnet crystals.

Subgroup $B_{2}$, ilmenite lamella only type (Prp 49-68; Alm 20-38; Grs 12-19 mol\%; $\mathrm{Cr}_{2} \mathrm{O}_{3}$ 0.4-2.5 wt\%), shows red to reddish-brown color and contains exsolved 
a
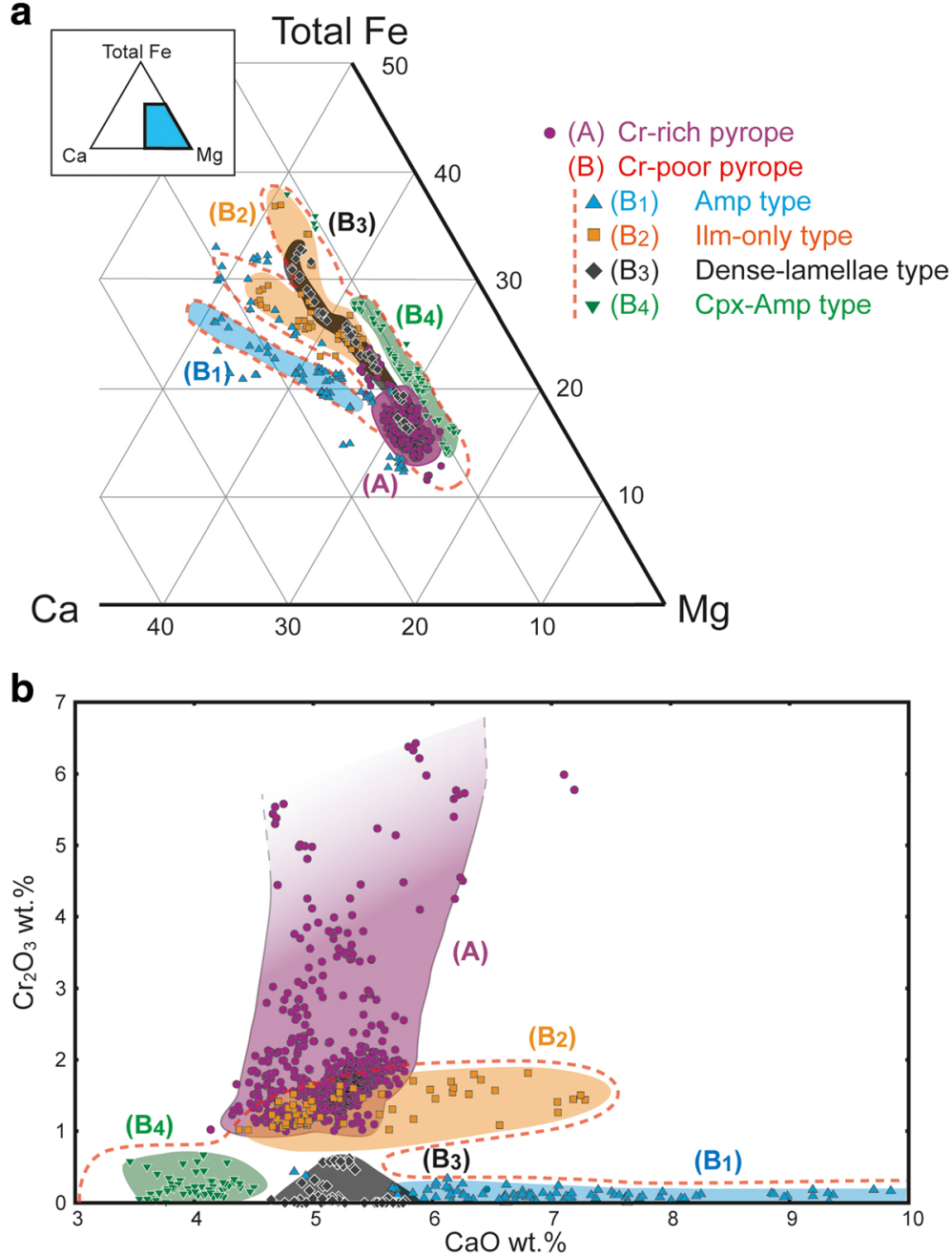

Fig. 2 Compositions of group $A$ and subgroups $B_{1}, B_{2}, B_{3}$, and $B_{4}$ pyrope from Garnet Ridge. a Ca-Mg-Fe triangle showing grossular-pyropealmandine components. $\mathbf{b} \mathrm{CaO}$ vs $\mathrm{Cr}_{2} \mathrm{O}_{3}$ (wt\%). The four subgroups in group $\mathrm{B}$ : $\mathrm{Cr}$-poor are characterized by low- $\mathrm{Cr}_{2} \mathrm{O}_{3}$ contents and varied $\mathrm{CaO}$ contents

lamellae of ilmenite only (Fig. 1 and Table 1); no other exsolved phases are recognized. Olivine, orthopyroxene, and clinopyroxene inclusions occur in $\mathrm{B}_{2}$ pyrope hosts. Composite fluid inclusions consisting of gas, liquid $\left(\mathrm{H}_{2} \mathrm{O}\right)$, and solid phases (rutile, chlorite, calcite, and barite) are observed in some $B_{2}$ garnet grains.

Subgroup $B_{3}$, dense lamellae type (Prp 54-72; Alm 18-33; Grs 12-15 mol\%), appear very dark due to abundant, densely packed exsolution lamellae of rutile, amphibole, and ilmenite with minor amounts of clinopyroxene, apatite, and srilankite (Fig. 1 and Table 1). Carbonate (magnesite and dolomite) inclusions arranged along curved planes are sometimes identified. Exsolved clinopyroxene crystals occur as long needles (approx. $300 \times$ $10 \mu \mathrm{m})$, short needles $(50 \times 10 \mu \mathrm{m})$, coarse-grained columns $(75 \times 50 \mu \mathrm{m})$, and fine-grained columns $(25 \times$ $20 \mu \mathrm{m})$ together with rutile, ilmenite, srilankite, apatite, and amphibole. These various occurrences of exsolved clinopyroxene occur within single grains of $\mathrm{B}_{3}$ pyrope. Clinopyroxene exsolution from garnet is regarded as evidence of supersilicic (majoritic) compositions of precursor garnet at UHP conditions (Moore and Gurney 1985). Some exsolved clinopyroxene needles and columns are sufficiently coarse-grained $(>10 \mu \mathrm{m}$ across) for quantitative analysis by EPMA, and all of the analyzed grains have Na-bearing diopside or omphacite compositions (Di 68-77 mol\%; $\mathrm{Na}_{2} \mathrm{O}$ 2.4-4.7 wt\%). Exsolved clinopyroxene lamellae in a single host garnet grain have homogeneous compositions, but lamellae in different garnet host crystals may have different compositions. Such grain by grain variations of exsolved clinopyroxene compositions probably reflect differenced in $\mathrm{Mg}, \mathrm{Fe}$, and $\mathrm{Na}$ contents and excess $\mathrm{Si}$ of precursor host garnet prior to exsolution. 
Table 2 Representative chemical compositions of pyrope from Garnet Ridge

\begin{tabular}{|c|c|c|c|c|c|}
\hline \multirow[b]{3}{*}{ Wt.\% } & \multirow{3}{*}{$\begin{array}{l}\text { (A) Cr-rich } \\
\text { pyrope }\end{array}$} & \multicolumn{4}{|c|}{ (B) Cr-poor pyrope } \\
\hline & & \multirow{2}{*}{$\begin{array}{l}B_{1} \\
\text { Amp }\end{array}$} & \multirow{2}{*}{$\begin{array}{l}\mathrm{B}_{2} \\
\text { Ilm-only }\end{array}$} & \multirow{2}{*}{$\begin{array}{l}\mathrm{B}_{3} \\
\text { Dense lamellae }\end{array}$} & \multirow{2}{*}{$\begin{array}{l}\mathrm{B}_{4} \\
\text { Cpx-Amp }\end{array}$} \\
\hline & & & & & \\
\hline $\mathrm{SiO}_{2}$ & 41.91 & 42.24 & 41.02 & 41.32 & 40.40 \\
\hline $\mathrm{TiO}_{2}$ & 0.09 & 0.05 & 0.14 & 0.10 & 0.06 \\
\hline $\mathrm{Al}_{2} \mathrm{O}_{3}$ & 22.30 & 23.36 & 21.66 & 23.01 & 22.72 \\
\hline $\mathrm{Cr}_{2} \mathrm{O}_{3}$ & 1.71 & 0.13 & 1.46 & 0.01 & 0.04 \\
\hline $\mathrm{FeO}^{\mathrm{a}}$ & 8.80 & 9.26 & 13.82 & 14.49 & 19.7 \\
\hline $\mathrm{MnO}$ & 0.36 & 0.38 & 0.54 & 0.41 & 0.45 \\
\hline $\mathrm{MgO}$ & 19.31 & 18.75 & 15.81 & 15.85 & 13.33 \\
\hline $\mathrm{CaO}$ & 5.43 & 5.99 & 5.43 & 4.93 & 3.41 \\
\hline $\mathrm{Na}_{2} \mathrm{O}$ & 0.02 & 0.02 & 0.03 & 0.05 & 0.05 \\
\hline $\mathrm{K}_{2} \mathrm{O}$ & 0.00 & 0.00 & 0.00 & 0.00 & 0.00 \\
\hline Total & 99.92 & 100.18 & 99.91 & 100.17 & 100.15 \\
\hline Cations & \multicolumn{5}{|c|}{ Number of cations on the basis of 12 oxygen } \\
\hline $\mathrm{Si}$ & 3.000 & 3.009 & 3.007 & 3.007 & 3.001 \\
\hline $\mathrm{Ti}$ & 0.005 & 0.003 & 0.008 & 0.006 & 0.003 \\
\hline Al & 1.881 & 1.961 & 1.871 & 1.974 & 1.989 \\
\hline $\mathrm{Cr}$ & 0.097 & 0.008 & 0.085 & 0.001 & 0.002 \\
\hline $\mathrm{Fe}^{3+}$ & 0.019 & 0.023 & 0.034 & 0.016 & 0.004 \\
\hline $\mathrm{Fe}^{2+}$ & 0.498 & 0.517 & 0.797 & 0.857 & 1.218 \\
\hline $\mathrm{Mn}$ & 0.022 & 0.023 & 0.034 & 0.025 & 0.029 \\
\hline $\mathrm{Mg}$ & 2.060 & 1.991 & 1.728 & 1.719 & 1.476 \\
\hline $\mathrm{Ca}$ & 0.416 & 0.457 & 0.426 & 0.384 & 0.271 \\
\hline $\mathrm{Na}$ & 0.002 & 0.002 & 0.004 & 0.007 & 0.006 \\
\hline K & 0.000 & 0.000 & 0.000 & 0.000 & 0.000 \\
\hline Total & 7.999 & 7.994 & 7.992 & 7.996 & 8.001 \\
\hline
\end{tabular}

Subgroup $\mathrm{B}_{4}$, clinopyroxene-amphibole lamellae type garnets (Prp 61-76; Alm 13-27; Grs 6-11 mol\%) occur as light-brown-colored crystals with exsolution lamellae of pyroxene, amphibole, rutile, and minor ilmenite. The exsolution lamellae in this subgroup are not as densely packed as in subgroup $B_{3}$ garnet (Fig. 1), and occurrences of exsolved amphibole in $B_{4}$ are rarer than in subgroups $\mathrm{B}_{1}$ and $\mathrm{B}_{4}$. Clinopyroxene and amphibole lamellae tend to occur in the central domains of typical $\mathrm{B}_{4}$ garnet grains. Thin rims (width ca. $200 \mu \mathrm{m}$ ) lacking any exsolved lamellae phases surround the lamellaebearing central domains. Exsolved clinopyroxene occurs as needle-shaped (ca. $180 \times 25 \mu \mathrm{m}$ ) and short columnarshaped (ca. $75 \times 50 \mu \mathrm{m})$ crystals and sometime occurs with rutile, ilmenite, and amphibole in composite lamellae. Exsolved clinopyroxene has chemical compositions of Na-bearing diopside to omphacite (Di $60-85 \mathrm{~mol} \%$; $\mathrm{Na}_{2} \mathrm{O}$ 1.4-5.3 wt\%).

\section{Exsolved amphibole in pyrope}

\section{Description under microscope}

Exsolved amphibole occurs in garnet subgroups $B_{1}, B_{3}$, and $B_{4}$. Textures of exsolved amphibole were observed as both (1) monomineralic hexagonal or rhombic prisms and tablets and (2) multimineralic needles or blades composed of amphibole with other exsolved phases. Both types of lamellae are oriented in four directions corresponding crystal directions of garnet host, similar to the first report on amphibole lamellae by Song et al. (2005) that suggested that amphibole lamellae are oriented in four directions corresponding the isometric form $\{111\}$ of garnet host.

In subgroup $\mathrm{B}_{1}$, amphibole lamella type garnet, monomineralic prisms and tablets of amphibole occur as coarse-grains $(80 \times 20 \mu \mathrm{m}$ on average $)$ and finegrains $(20 \times 10 \mu \mathrm{m}$ on average), respectively. Long and short multiphase needles/blades (ca. $350 \times 15$ and $25 \times 10 \mu \mathrm{m}$, respectively) are composed of amphibole with rutile, ilmenite, srilankite, and apatite.

In subgroup $B_{3}$, dense lamellae type garnet, multiphase needles and blades of amphibole occur as long and short (ca. $400 \times 10$ and $70 \times 15 \mu \mathrm{m}$, respectively) crystals and occur with rutile, ilmenite, srilankite, apatite, and clinopyroxene.

In subgroup $\mathrm{B}_{4}$, clinopyroxene and amphibole lamellae type garnet, monomineralic prisms/tablets and multiphase needles/blades associated with amphibole have sizes of ca. $80 \times 30$ and $400 \times 20 \mu \mathrm{m}$, similar to the size of coarse-grained monomineralic/composite exsolved amphibole of $B_{1}$ and $B_{3}$. Fine-grained monomineralic/composite exsolved amphibole is very rare in subgroup $B_{4}$.

\section{Laser Raman study}

Exsolved amphibole was identified by laser Raman spectroscopy (Fig. 3). In subgroup $\mathrm{B}_{1}$, amphiboles of monomineralic prisms/tablets and multiphase needles/ blades show Raman peaks at 235, 670, and $3708 \mathrm{~cm}^{-1}$ in each spectrum. In subgroup $B_{3}$, amphibole has similar Raman peaks at 227,659 , and $3708 \mathrm{~cm}^{-1}$, regardless of occurrence (monomineralic/multimineralic) or morphology (coarse/fine or prism/tablet/needles/ blades). In subgroup $B_{4}$, coarse-grained amphiboles of monomineralic prisms/tablets and multiphase needles/ blades have Raman spectra with peaks at 225, 672, and $3710 \mathrm{~cm}^{-1}$.

Two-dimensional Raman maps were collected in a few cases to show distributions of exsolved amphibole with other exsolved phases in garnet. Raman intensity maps from a garnet crystal of subgroup $B_{3}$ in Fig. 4 show the distributions of amphibole (Fig. 4d) and other Ti-bearing phases such as rutile and ilmenite (Fig. 4e). Amphibole occurs as coarse-grained multiphase blades and needles 


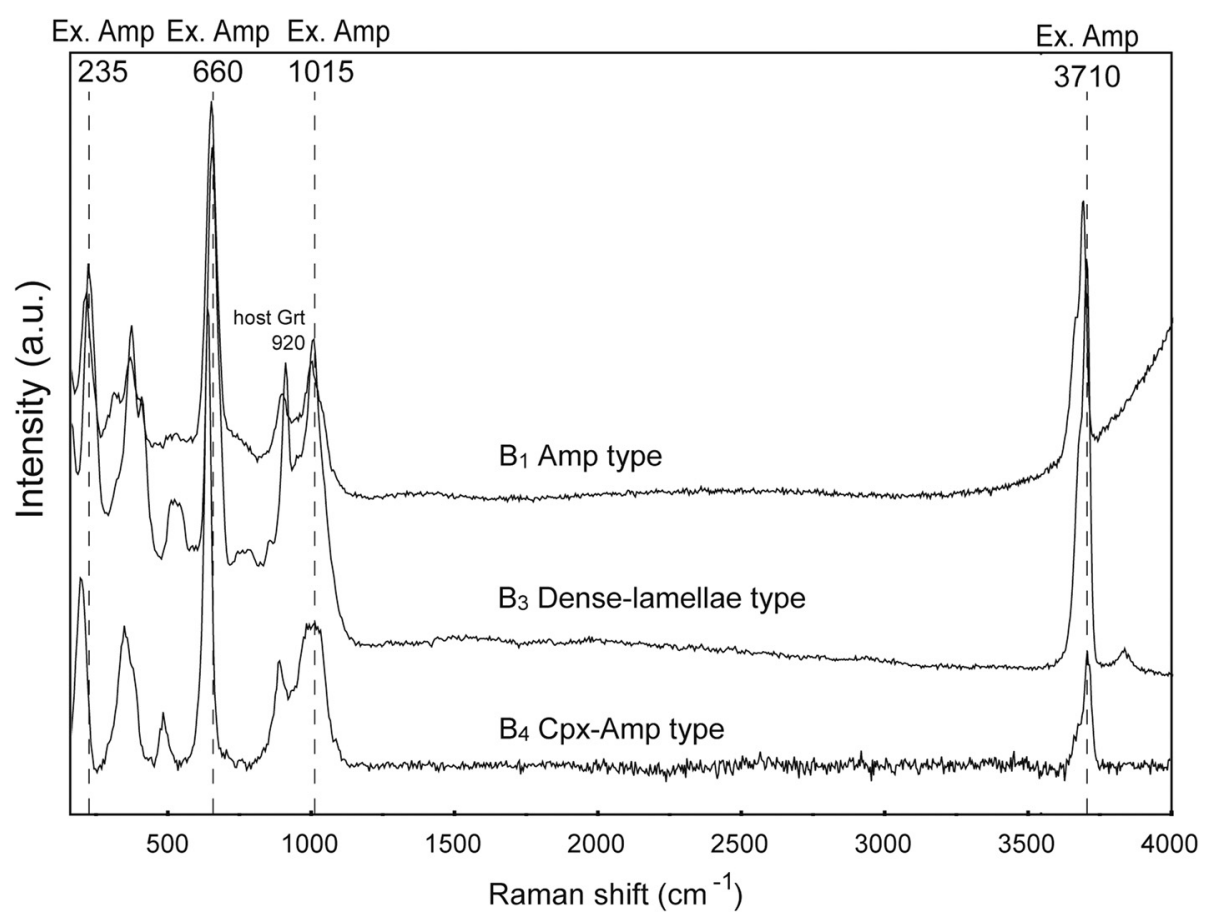

Fig. 3 Representative Raman spectra of exsolved amphibole in pyrope from subgroups: $B_{1}$ (amphibole lamella type); $B_{3}$ (dense lamellae type); and $\mathrm{B}_{4}$ (clinopyroxene-amphibole lamellae type)

intergrown together with rutile and ilmenite in this garnet host (Fig. 4). The intergrowth textures suggest that exsolution of amphibole, rutile, and ilmenite occurred at the same stage.

\section{Chemistry}

Chemical compositions of exsolved amphibole $(>10 \mu \mathrm{m}$ across) were analyzed with an EMP-WDS. Chemical compositions of exsolved amphibole in subgroups $B_{1}$, $\mathrm{B}_{3}$, and $\mathrm{B}_{4}$ are listed in Table 3. Based on the EMP analyses, exsolved amphiboles in a given host garnet crystal have homogeneous compositions, but exsolved amphiboles from different host garnets may have different compositions.

In subgroup $B_{1}$, amphibole contains up to $1.2 \mathrm{Na}$ atoms per formula unit (apfu, based on 23 oxygen). A representative composition of exsolved amphiboles in $B_{1}$ is $\mathrm{Na}_{1.10}\left(\mathrm{Ca}_{1.90} \mathrm{Na}_{0.10}\right)\left(\mathrm{Mg}_{3.79} \mathrm{Ni}_{0.06} \mathrm{Fe}_{0.32} \mathrm{Al}_{0.79}\right)\left(\mathrm{Al}_{1.95-}\right.$ $\left.\mathrm{Si}_{6.05}\right) \mathrm{O}_{22}\left(\mathrm{OH}_{1.97}, \mathrm{Cl}_{0.03}\right)$; this is a solid solution of pargasite, $\mathrm{NaCa}_{2} \mathrm{Mg}_{4} \mathrm{AlSi}_{6} \mathrm{Al}_{2} \mathrm{O}_{22}(\mathrm{OH})_{2}$, magnesiohastingsite, $\mathrm{NaCa}_{2} \mathrm{Mg}_{4} \mathrm{Fe}^{3+} \mathrm{Si}_{6} \mathrm{Al}_{2} \mathrm{O}_{22}(\mathrm{OH})_{2}$, and magnesiokatophorite, $\mathrm{NaNaCaMg}{ }_{4} \mathrm{AlSi}_{7} \mathrm{AlO}_{22}(\mathrm{OH})_{2}$. According to the classification of Leake et al. (1997), this composition is classified as pargasite.

In different garnet grains from subgroup $B_{3}$, amphibole shows wider variations of $\mathrm{Na}(1.0-1.6 \mathrm{apfu})$ compared to subgroup $B_{1}$ amphibole. A representative composition is $\quad \mathrm{Na}_{0.92}\left(\mathrm{Ca}_{1.43} \mathrm{Na}_{0.59}\right)\left(\mathrm{Mg}_{3.39} \mathrm{Ni}_{0.05-}\right.$ $\left.\mathrm{Fe}_{0.50} \mathrm{Al}_{1.03} \mathrm{Ti}_{0.10}\right)\left(\mathrm{Al}_{1.90} \mathrm{Si}_{6.10}\right) \mathrm{O}_{22}\left(\mathrm{OH}_{1.90}, \mathrm{O}_{0.10}\right)$. This chemical formula is a solid solution of magnesiotaramite, $\mathrm{Na}(\mathrm{CaNa}) \mathrm{Mg}_{3} \mathrm{AlFe}^{3+} \mathrm{Si}_{6} \mathrm{Al}_{2} \mathrm{O}_{22}(\mathrm{OH})_{2}$, and pargasite.

Exsolved amphibole in subgroup $\mathrm{B}_{4}$ is characterized by higher $\mathrm{Si}$ contents (7.01-7.09 apfu) than the amphibole lamellae in $B_{1}$ and $B_{3}$. A representative composition is $\mathrm{Na}_{0.90}\left(\mathrm{Ca}_{1.40} \mathrm{Na}_{0.60}\right)_{2.00}\left(\mathrm{Mg}_{4.30} \mathrm{Fe}_{0.28} \mathrm{~A}\right.$ $\left.\mathrm{l}_{0.43}\right)_{5.01}\left(\mathrm{Al}_{0.99} \mathrm{Si}_{7.01}\right)_{8.00} \mathrm{O}_{22}\left(\mathrm{OH}_{2.00}\right)_{2}$. This chemical formula is a solid solution of magnesiokatophorite, $\mathrm{Na}(\mathrm{NaCa}) \mathrm{Mg}_{4} \mathrm{AlSi}_{7} \mathrm{AlO}_{22}(\mathrm{OH})_{2}$, and edenite, $\mathrm{NaCa}_{2} \mathrm{Mg}_{5}$ $\mathrm{Sl}_{7} \mathrm{AlO}_{22}(\mathrm{OH})_{2}$; these endmembers of the amphibole group have slightly high $\mathrm{Si}$ contents compared to pargasite (Si 6 apfu based on 23 oxygens). Na contents are similar to those in exsolved amphiboles in subgroups $B_{1}$ and $B_{3}$.

\section{D mapping for major/minor elements}

X-ray elemental maps of some exsolved amphibole grains and surrounding host garnet were collected from a garnet grain of subgroup $B_{1}$. For several elements, garnet host domains surrounding amphibole lamellae show little variation in compositions; however, in some cases, garnet is depleted in $\mathrm{Ca}, \mathrm{Ti}$, and $\mathrm{Na}$ close to the amphibole lamellae (Fig. 5). These distributions are interpreted as a depletion halos caused by amphibole exsolution from host garnet. 


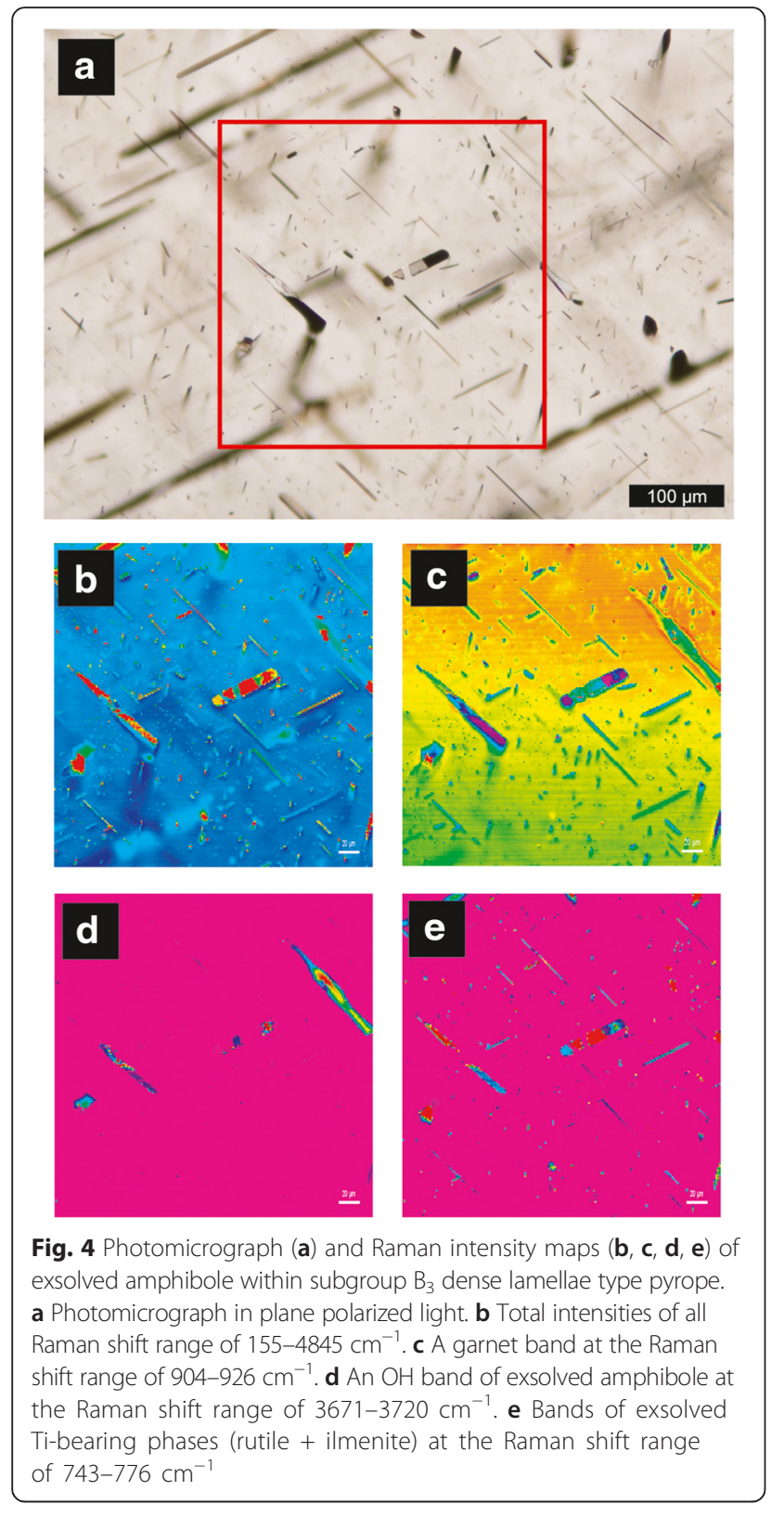

\section{IR spectra and water contents of pyrope \\ Group A: Cr-rich pyrope}

IR spectra obtained from group A, Cr-rich pyrope crystals stop, have dominant absorption bands with peaks near $3575 \mathrm{~cm}^{-1}$ and minor bands at $3660-3680 \mathrm{~cm}^{-1}$ (Fig. 6 and Table 4). The dominant peaks near $3575 \mathrm{~cm}^{-1}$ are similar to an $\mathrm{OH}$ band in pyrope reported by Aines and Rossman (1984). OH concentrations in the host garnet range from below the detection limit (1 ppmw) to 115 ppmw $\mathrm{H}_{2} \mathrm{O}$ (Fig. 8).

\section{Group B: Cr-poor pyrope}

Obtained IR spectra show strong absorption bands near $3575 \mathrm{~cm}^{-1}$ and relatively weak bands at $3660-3680 \mathrm{~cm}^{-1}$,
Table 3 Representative chemical compositions of exsolved amphibole in garnet subgroups: $B_{1}$ (amphibole lamella type), $B_{3}$ (dense lamellae type), and $B_{4}$ (clinopyroxene-amphibole lamellae type)

\begin{tabular}{|c|c|c|c|c|c|c|}
\hline \multirow[b]{2}{*}{ Wt. \% } & \multicolumn{6}{|c|}{$\begin{array}{l}\text { Exsolved amphibole } \\
\text { Host garnet: (B) Cr-poor pyrope }\end{array}$} \\
\hline & $\mathrm{B} 1$ & & B3 & & B4 & \\
\hline $\mathrm{SiO}_{2}$ & 43.58 & 42.98 & 43.90 & 43.62 & 50.24 & 50.51 \\
\hline $\mathrm{TiO}_{2}$ & 0.35 & 0.33 & 1.09 & 0.97 & 0.23 & 0.19 \\
\hline $\mathrm{Al}_{2} \mathrm{O}_{3}$ & 16.13 & 16.38 & 18.25 & 16.71 & 8.65 & 8.93 \\
\hline $\mathrm{Cr}_{2} \mathrm{O}_{3}$ & 0.12 & 0.14 & 0.07 & 0.00 & 0.19 & 0.16 \\
\hline $\mathrm{FeO}^{\mathrm{a}}$ & 2.21 & 2.49 & 3.97 & 3.75 & 2.40 & 2.38 \\
\hline $\mathrm{CaO}$ & 12.64 & 12.37 & 9.33 & 11.54 & 9.37 & 9.12 \\
\hline $\mathrm{MnO}$ & 0.03 & 0.00 & 0.03 & 0.02 & 0.00 & 0.02 \\
\hline $\mathrm{MgO}$ & 18.00 & 18.12 & 15.71 & 17.18 & 20.67 & 20.48 \\
\hline $\mathrm{NiO}$ & 0.76 & 0.38 & 0.36 & 0.34 & 0.13 & 0.09 \\
\hline $\mathrm{Na}_{2} \mathrm{O}$ & 4.26 & 3.84 & 5.62 & 3.81 & 5.55 & 5.35 \\
\hline $\mathrm{K}_{2} \mathrm{O}$ & 0.01 & 0.00 & 0.02 & 0.00 & 0.31 & 0.30 \\
\hline $\mathrm{Cl}$ & 0.10 & 0.02 & 0.00 & 0.00 & 0.02 & 0.04 \\
\hline Total & 98.18 & 97.05 & 98.36 & 97.94 & 97.77 & 97.57 \\
\hline Cations & \multicolumn{6}{|c|}{ Number of cation based on 23 oxygen } \\
\hline $\mathrm{Si}$ & 6.137 & 6.104 & 6.145 & 6.142 & 7.006 & 7.039 \\
\hline $\mathrm{Ti}$ & 0.037 & 0.036 & 0.115 & 0.103 & 0.024 & 0.020 \\
\hline Al & 2.677 & 2.742 & 3.011 & 2.774 & 1.422 & 1.467 \\
\hline $\mathrm{Cr}$ & 0.013 & 0.016 & 0.008 & 0.000 & 0.021 & 0.018 \\
\hline $\mathrm{Fe}^{2+}$ & 0.260 & 0.296 & 0.465 & 0.442 & 0.280 & 0.277 \\
\hline $\mathrm{Ca}$ & 1.907 & 1.882 & 1.399 & 1.741 & 1.400 & 1.362 \\
\hline $\mathrm{Mg}$ & 3.778 & 3.836 & 3.278 & 3.606 & 4.297 & 4.254 \\
\hline $\mathrm{Mn}$ & 0.003 & 0.000 & 0.004 & 0.002 & 0.000 & 0.002 \\
\hline $\mathrm{Ni}$ & 0.087 & 0.044 & 0.041 & 0.038 & 0.014 & 0.010 \\
\hline $\mathrm{Na}$ & 1.163 & 1.057 & 1.525 & 1.040 & 1.501 & 1.446 \\
\hline K & 0.001 & 0.000 & 0.004 & 0.000 & 0.054 & 0.053 \\
\hline Total & 16.064 & 16.011 & 15.995 & 15.889 & 16.023 & 15.955 \\
\hline $\mathrm{Cl}$ & 0.024 & 0.005 & 0.000 & 0.000 & 0.004 & 0.009 \\
\hline
\end{tabular}

${ }^{\mathrm{a}}$ Total Fe as FeO

both associated with structural $\mathrm{OH}$ in host garnet (Figs. 6 and 7; Table 4; see Aines and Rossman 1984). These two IR bands are similar to $\mathrm{OH}$ bands in group A garnet. Broad bands at ca. $3400 \mathrm{~cm}^{-1}$ were sometimes detected in subgroups $B_{1}$ and $B_{2}$. These broad bands are probably caused by molecular $\mathrm{H}_{2} \mathrm{O}$ in fluid inclusions (e.g., Libowitzky and Rossman 1997). Sharp bands at ca. $3710 \mathrm{~cm}^{-1}$, apparently due to $\mathrm{OH}$ in amphibole, were identified in subgroups $\mathrm{B}_{1}$, $\mathrm{B}_{3}$, and $\mathrm{B}_{4}$. $\mathrm{OH}$ concentrations in host garnet are estimated at as follows: $\mathrm{B}_{1} 3-42$ ppmw $\mathrm{H}_{2} \mathrm{O}, \mathrm{B}_{2} 27$ and 101 ppmw (two grains analyzed), $B_{3} 4-10$ ppmw, and $\mathrm{B}_{4} 2$ ppmw (one grain analyzed; see Fig. 8). Garnets from subgroups $B_{1}, B_{3}$, and $B_{4}$, all characterized by 

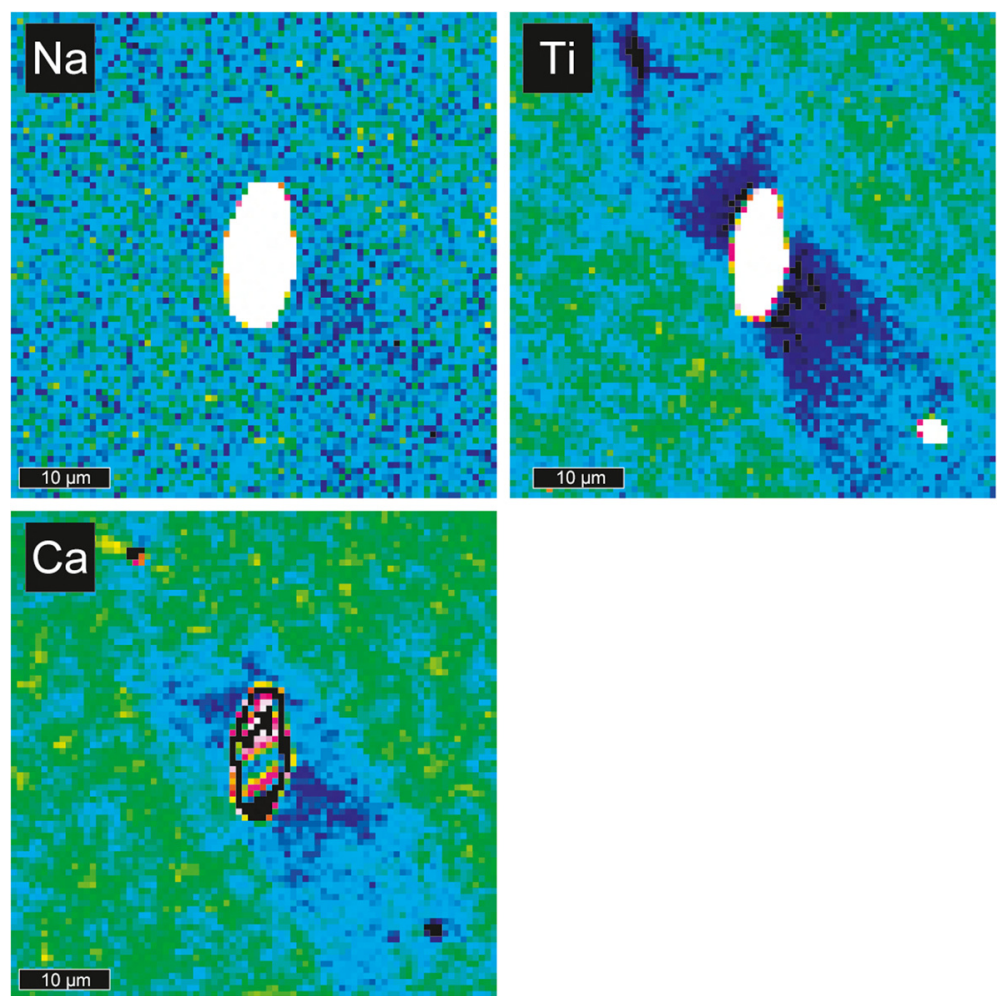

Fig. 5 X-ray images for $\mathrm{Na}-\mathrm{Ka}$, $\mathrm{Ti}-\mathrm{Ka}$, and $\mathrm{Ca}-\mathrm{Ka}$ of exsolved amphibole in $\mathrm{B}_{3}$ dense lamellae type garnet

amphibole-bearing exsolution lamellae, have lower water concentrations than group $\mathrm{A}$ and subgroup $\mathrm{B}_{2}$ garnets, which do not have exsolved amphibole.

\section{Discussion}

\section{Protoliths of garnet-bearing rocks underneath the Colorado Plateau}

Classification of kimberlitic garnet xenocrysts has been conducted based on chemistry and inclusions for many years (e.g., Dawson and Stephens 1975; Danchin and Wyatt 1979; Schulze 2003; Grütter et al. 2004). Schulze (2003) compiled published analyses of garnets from ultramafic xenoliths in kimberlite and proposed a method for distinguishing mantle vs. crustal origins of garnets based on $\mathrm{Mg} /(\mathrm{Mg}+\mathrm{Fe})$ and $\mathrm{Ca} /(\mathrm{Ca}+\mathrm{Mg})$. According to results of Schulze (2003), garnet with $\mathrm{Mg} /(\mathrm{Mg}+\mathrm{Fe})$ of $0.5-1$ and $\mathrm{Ca} /(\mathrm{Ca}+\mathrm{Mg})$ of $0.1-0.9$ probably has a mantle origin. Most analyses of the group A $[\mathrm{Mg} /(\mathrm{Mg}+\mathrm{Fe})=0.79-0.85$, $\mathrm{Ca} /(\mathrm{Ca}+\mathrm{Mg})=0.09-0.14]$ and group $\mathrm{B}[\mathrm{Mg} /(\mathrm{Mg}+\mathrm{Fe})=$ $0.56-0.85, \mathrm{Ca} /(\mathrm{Ca}+\mathrm{Mg})=0.08-0.65]$ pyropes of this study indicate mantle origins based on the criteria of Schulze (2003) (see their Fig. 1).

Grütter et al. (2004) proposed that $\mathrm{Mg}, \mathrm{Ca}, \mathrm{Fe}, \mathrm{Cr}$, and $\mathrm{Ti}$ contents of mantle-derived garnet can be used to distinguish 13 compositional types of garnet, each associated with a likely mantle rock-type. The group A pyrope of this study has a composition $\left(\mathrm{Pyp}_{67-74}\right.$,
4-6 wt\% $\mathrm{CaO}$, and up to $6.4 \mathrm{wt} \% \mathrm{Cr}_{2} \mathrm{O}_{3}$ ) similar to garnet from lherzolite or Fe-rich pyroxenite, based on the classification of Grütter et al. (2004), see $\mathrm{CaO}$ vs $\mathrm{Cr}_{2} \mathrm{O}_{3}$ diagram in Fig. 7). The inclusion assemblage in group $\mathrm{A}$ garnet is olivine-orthopyroxene-clinopyroxene, each occurring in similar abundances (Table 1). These clues suggest that the group A pyrope crystals came from lherzolite or olivinewebsterite.

Chemical compositions of group B are characterized by low $\mathrm{Cr}$ contents and wide variations of $\mathrm{Mg}$ and $\mathrm{Ca}$ compared to group A (Fig. 2b). The compositions of subgroup $\mathrm{B}_{1}$ ( $\mathrm{Pyp}_{49-66}, 5-10 \mathrm{wt} \% \mathrm{CaO}$, and up to $0.5 \mathrm{wt} \% \mathrm{Cr}_{2} \mathrm{O}_{3}$ ) and $\mathrm{B}_{3}$ ( $\mathrm{Pyp}_{54-72}, 4-6 \mathrm{wt} \% \mathrm{CaO}$, and up to $\left.0.6 \mathrm{wt} \% \mathrm{Cr}_{2} \mathrm{O}_{3}\right)$ are similar to those of garnet in pyroxenite (e.g., mantle eclogite, pyroxenite, and websterite) or the low-Ca pyroxenite in Grütter et al. (2004). The trapped inclusions in subgroups $B_{1}$ and $B_{3}$ are dominantly clinopyroxene, whereas olivine and orthopyroxene were not identified at all (Table 1). Therefore, the host rocks of subgroups $B_{1}$ and $B_{3}$ are probably garnetbearing clinopyroxenites.

Subgroup $\mathrm{B}_{4}$ pyrope crystals have compositions that are relatively poor in $\mathrm{Ca}$ and $\mathrm{Cr}\left(\mathrm{Pyp}_{61-76}, 3-4 \mathrm{wt} \%\right.$ $\mathrm{CaO}$, and up to $0.6 \mathrm{wt} \% \mathrm{Cr}_{2} \mathrm{O}_{3}$ ) compared to subgroups $\mathrm{B}_{1}$ and $\mathrm{B}_{3}$ (Fig. 2b). The $\mathrm{B}_{4}$ pyrope compositions are similar to garnets from low-Ca pyroxenite (Grütter et al. 2004). In addition, subgroup $B_{4}$ garnet contains trapped 

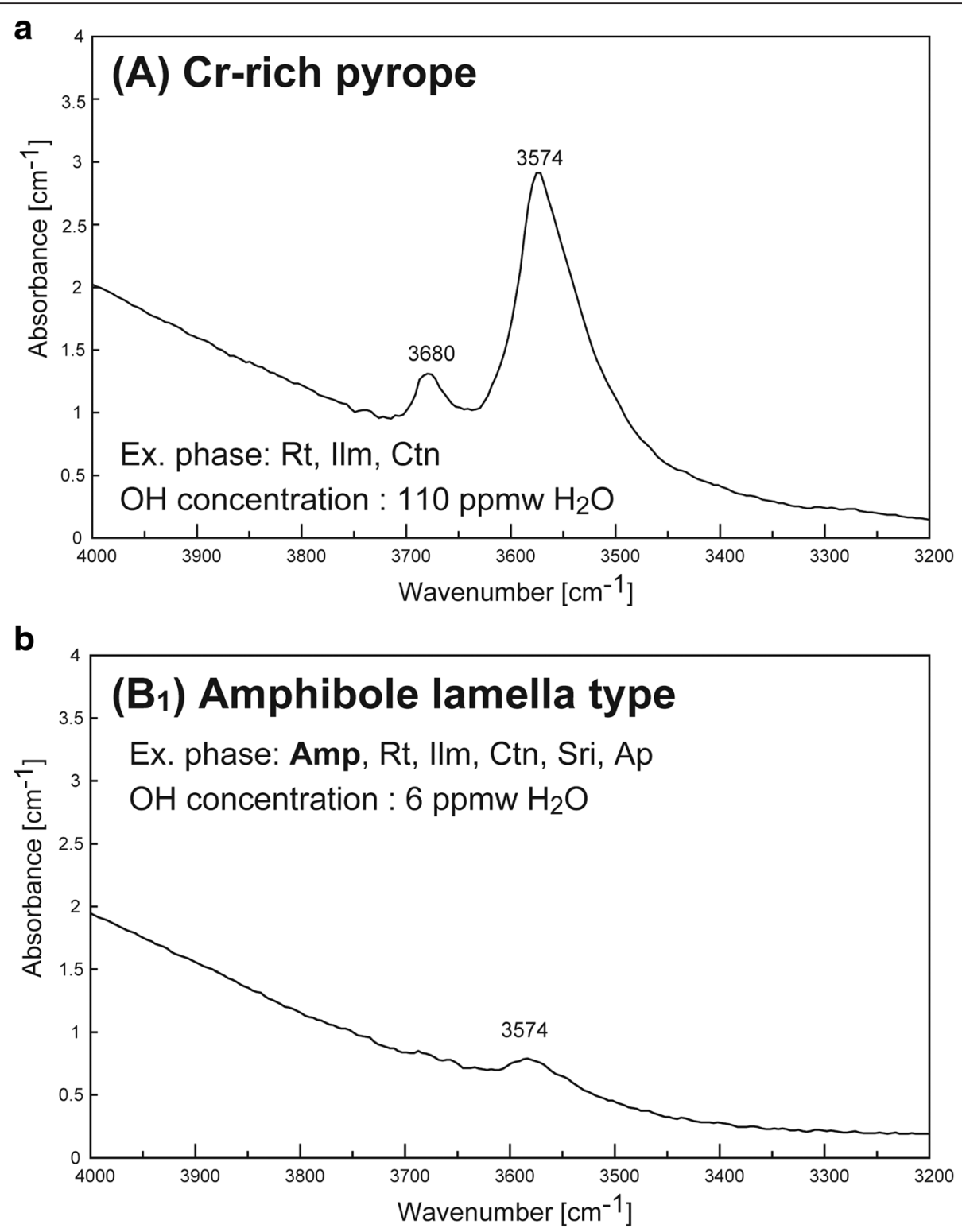

Fig. 6 Representative micro-FTIR absorption spectra of a group A, Cr-rich pyrope, and b subgroup B, amphibole lamella type pyrope

inclusions of olivine and orthopyroxene, but clinopyroxene inclusions were not identified (Table 1). This inclusion assemblage combined with the $\mathrm{Ca}$-, $\mathrm{Cr}$-poor compositions suggest that subgroup $\mathrm{B}_{4}$ garnet likely originates from garnet-bearing olivine orthopyroxenite or harzburgite.

Subgroup $\mathrm{B}_{2}$ has slightly higher $\mathrm{Cr}$ contents ( $\mathrm{Pyp}_{49-68}$, 4-7.5 wt\% $\mathrm{CaO}$, and 1-2 wt\% $\mathrm{Cr}_{2} \mathrm{O}_{3}$ ) than subgroups $\mathrm{B}_{1}, \mathrm{~B}_{3}$, and $\mathrm{B}_{4}$ (Fig. 2b). The composition of subgroup $\mathrm{B}_{2}$ garnet is similar to the compositions of Fe-rich pyroxenitic garnet reported by Grütter et al. (2004). Subgroup $\mathrm{B}_{2}$ garnet contains trapped inclusions of olivine, orthopyroxene, clinopyroxene, and fluid inclusions (Table 1). We infer that the host rock of subgroup $B_{2}$ garnet is probably hydrated garnet-bearing lherzolite or olivine-websterite.

Group A (lherzolitic or websteritic) garnet is the most abundant type of garnet that we identified at Garnet Ridge. Garnet-lherzolite and olivine-websterite are therefore considered to be dominant and typical garnet-bearing constituents of upper mantle underneath the Colorado Plateau. The group A garnet has a limited chemical variation in $\mathrm{Mg}$-Fe-Ca contents, whereas each subgroup of group B (pyroxenitic origins) has a wider chemical range (Fig. 2a); some garnets of group B have $\mathrm{Mg}-\mathrm{Fe}-\mathrm{Ca}$ contents that overlap with group A garnet but many in group $\mathrm{B}$ have more $\mathrm{Ca}$ - and/or Fe-rich compositions than the concentrated chemical range of group A (Fig. 2). 
Table 4 Micro-FTIR analyses of pyrope from Garnet Ridge

\begin{tabular}{|c|c|c|c|c|c|c|c|c|c|}
\hline \multicolumn{5}{|l|}{ Chemistry } & \multicolumn{5}{|l|}{ Micro-FTIR analysis } \\
\hline Classification & Sample no. & $\operatorname{Pyp}_{(\mathrm{mol} / \%)}$ & $\mathrm{CaO}_{(\mathrm{wt} \%)}$ & $\mathrm{Cr}_{2} \mathrm{O}_{3}(\mathrm{wt} \%)$ & Band positions $\left(\mathrm{cm}^{-1}\right)$ & & & Int. Abs. ${ }^{a}\left(\mathrm{~cm}^{-1}\right)$ & OH contents (ppmw) \\
\hline A Cr-rich pyrope & S1_Pr1 & 69 & 5.5 & 2.2 & & & 3573 & 41.3 & 24 \\
\hline A Cr-rich pyrope & S1_Pr2 & 70 & 5.5 & 2.3 & & 3678 & 3573 & 83.7 & 48 \\
\hline A Cr-rich pyrope & S1_Pr3 & 70 & 4.9 & 2.8 & & 3678 & 3572 & 164.9 & 95 \\
\hline A Cr-rich pyrope & S2_Pr1 & 69 & 5.3 & 5.1 & & 3673 & 3571 & 136.8 & 78 \\
\hline A Cr-rich pyrope & S2_Pr2 & 69 & 5.2 & 2.3 & & 3680 & 3571 & 60.3 & 35 \\
\hline A Cr-rich pyrope & S2_R3 & 67 & 5.1 & 2.3 & & 3675 & 3571 & 201.0 & 115 \\
\hline$B_{1}$ Amp type & $\mathrm{S} 1 \_\mathrm{Br} 1$ & 59 & 7.6 & 0.0 & & & 3575 & 41.5 & 24 \\
\hline$B_{1}$ Amp type & $\mathrm{S} 2 \_\mathrm{Br} 2$ & 49 & 7.6 & 0.0 & & 3674 & 3578 & 73.3 & 42 \\
\hline $\mathrm{B}_{1}$ Amp type & S4_Br1 & 65 & 7.3 & 0.1 & & & 3574 & 10.7 & 6 \\
\hline$B_{1}$ Amp type & S6_Br1 & 62 & 7.0 & 0.1 & & & 3569 & 4.8 & 3 \\
\hline $\mathrm{B}_{2}$ IIm-only type & $\mathrm{S} 2 \_\mathrm{Br} 2$ & 57 & 5.6 & 1.8 & & 3666 & 3573 & 176.7 & 101 \\
\hline $\mathrm{B}_{2}$ IIm-only type & S5_Br2 & 60 & 6.3 & 1.8 & & 3653 & 3549 & 46.9 & 27 \\
\hline $\mathrm{B}_{3}$ Dense lamellae type & 0909B_Bl3_1 & 73 & 4.6 & 0.3 & & & 3580 & 6.7 & 4 \\
\hline $\mathrm{B}_{3}$ Dense lamellae type & 0909B_B13_2 & 69 & 5.3 & 0.4 & 3718(Amp) & & 3570 & 17.2 & 10 \\
\hline $\mathrm{B}_{3}$ Dense lamellae type & 0909B_Bl3_3 & 69 & 5.1 & 0.3 & & & 3572 & 7.5 & 4 \\
\hline $\mathrm{B}_{3}$ Dense lamellae type & 0909B_Bl3_4 & 60 & 5.1 & 1.0 & $3712_{(\mathrm{Amp})} \quad 3684_{(\mathrm{Amp})}$ & & 3579 & 12.4 & 7 \\
\hline $\mathrm{B}_{4}$ Cpx-Amp type & S3_Br1 & 66 & 4.8 & 0.5 & & & 3569 & 4.0 & 2 \\
\hline
\end{tabular}

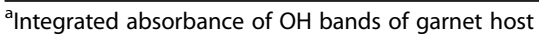

The wide chemical ranges of $\mathrm{Ca}$ and $\mathrm{Fe}$ in group $\mathrm{B}$ show linear variations in $\mathrm{Mg}$-Fe-Ca contents. In general, such linear chemical variations are interpreted as mixtures of two different compositions. Therefore, group A (typical lherzolitic/olivine-websteritic) pyrope may represent a primitive, Mg-rich endmember of the garnets at Garnet Ridge. The Ca- and Fe-rich compositional variations of the group $\mathrm{B}$ are likely products of interaction between the typical lherzolitic/olivine-websteritic garnet and $\mathrm{Ca} / \mathrm{Fe}$-rich media such as fluids (Fig. 9). A few garnet crystals of group $A$ and some garnet in subgroups $B_{2}$ and $\mathrm{B}_{3}$ have volatile-bearing inclusions of dolomite, magnesite, apatite, and chlorite (Table 1) and contain significant amounts of $\mathrm{OH}$ up to 115 ppmw in group A and up to 101 ppmw in the group B. These clues of volatile, $\mathrm{H}_{2} \mathrm{O}$-rich environments suggest that the chemical changes from the group A garnet to more $\mathrm{Ca} / \mathrm{Fe}-$ rich compositions were caused by fluid-mediated mantle metasomatism. During metasomatism, the host rocks of group B transformed from typical mantle lherzolites and olivine-websterites to pyroxenitic rocks (e.g., Sapienza et al. 2009; Vrijmoed et al. 2013).

\section{Exsolved amphibole-bearing garnet after hydrous Na-garnet}

The following points are critical for determining the origin of amphibole grains in pyrope from Garnet Ridge: (1) preferred orientation of amphibole grains controlled by crystal orientations of the host garnet; (2) depletion haloes of $\mathrm{Na}, \mathrm{Ca}$ and $\mathrm{Ti}$ in the host garnet surrounding amphibole grains; and (3) low $\mathrm{OH}$ contents in amphibole-bearing garnet host. Considering these observations, we infer that the oriented amphibole inclusions in pyrope crystals formed by exsolution from precursor $\mathrm{Na}-$ and $\mathrm{OH}$-rich garnet. Amphibole exsolution from garnet is rarely reported; we are aware of only one previous report on amphibole exsolution from North Qaidam UHP metamorphic belts, northern Tibet, NW China (Song et al. 2005).

Exsolved amphiboles in pyrope from Garnet Ridge contain significant amounts of $\mathrm{Na}$ (up to 1.6 apfu on the basis of 23 oxygen), and their chemistries approximate pargasite, $\mathrm{NaCa}_{2} \mathrm{Mg}_{4} \mathrm{AlSi}_{6} \mathrm{Al}_{2} \mathrm{O}_{22}(\mathrm{OH})_{2}$. The chemical formula of precursor garnet prior to amphibole exsolution was a solid solution that included the components necessary to exsolve amphibole. The precursor garnet before amphibole exsolution must have had a "hydrous Na-garnet" component, such as $\left(\mathrm{Mg}, \mathrm{Na}_{\mathrm{x}}^{+}\right)_{3}\left(\mathrm{Al}_{2-\mathrm{x}}\right.$, $\left.\mathrm{Mg}_{\mathrm{x}}\right)_{2} \mathrm{Si}_{3} \mathrm{O}_{12-2 \mathrm{x}}(\mathrm{OH})_{2 \mathrm{x}}$. This garnet was broken down by a reaction similar to the following:

$$
\begin{gathered}
\left(\mathrm{Mg}, \mathrm{Ca}, \mathrm{Na}_{\mathrm{x}}\right)_{3}\left(\mathrm{Al}_{2}-\mathrm{x}, \mathrm{Mg}_{\mathrm{x}}\right)_{2} \mathrm{Si}_{3} \mathrm{O}_{12}-2 \mathrm{x}(\mathrm{OH})_{2 \mathrm{x}} \\
\quad \rightarrow \mathrm{x} \mathrm{NaCa}{ }_{2}\left(\mathrm{Mg}_{4} \mathrm{Al}\right) \mathrm{Si}_{6} \mathrm{Al}_{2} \mathrm{O}_{22}(\mathrm{OH})_{2} \\
\quad+(1-2 \mathrm{x})(\mathrm{Mg}, \mathrm{Ca}) \mathrm{Al}_{2} \mathrm{Si}_{3} \mathrm{O}_{12} .
\end{gathered}
$$

The pargasite stability field is limited to pressures $<3 \mathrm{GPa}$ (Green 1973), indicating that breakdown of hydrous Na-garnet and formation of exsolved 

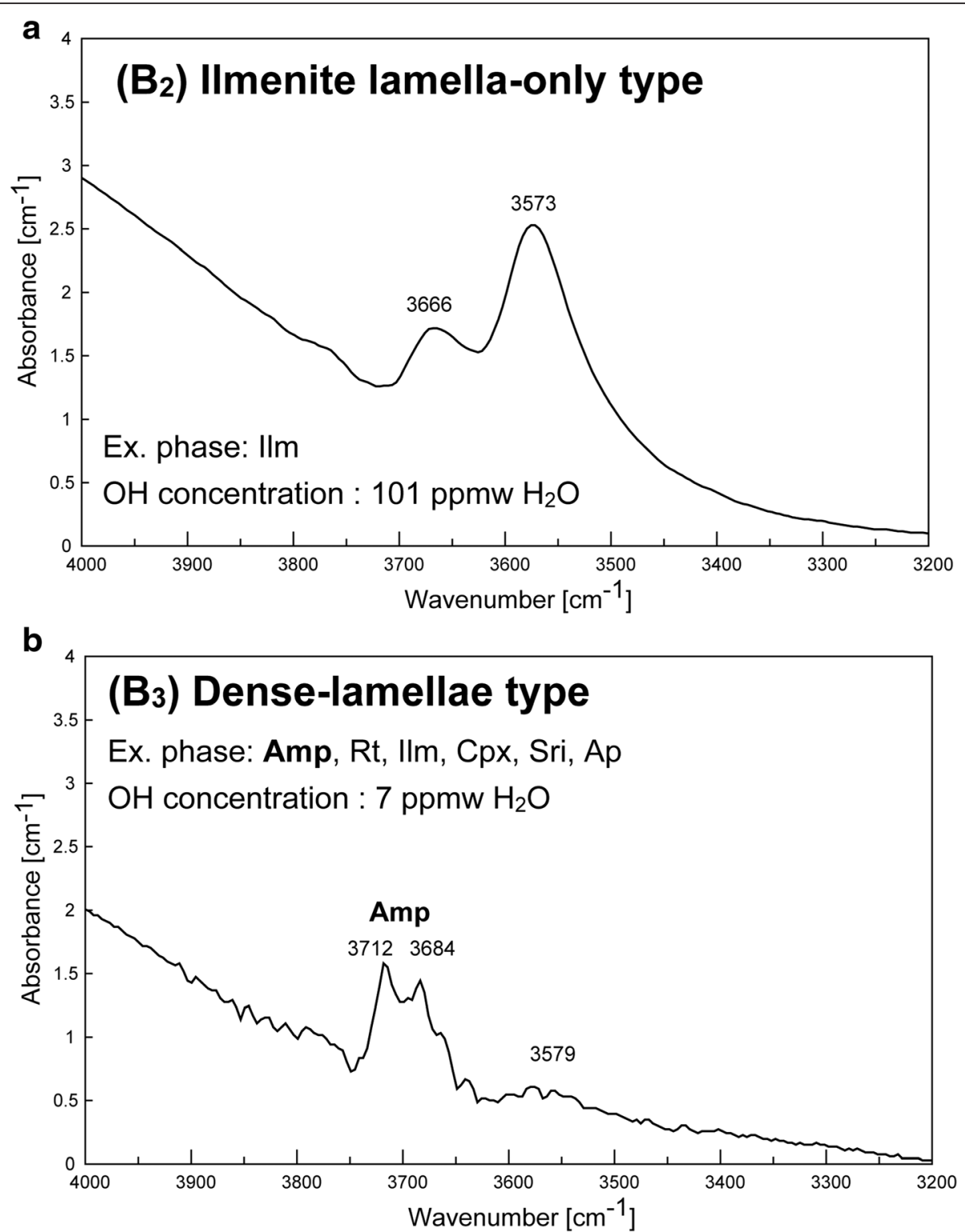

Fig. 7 Representative micro-FTIR spectra of a subgroup $B_{2}$, ilmenite lamella type pyrope, and $\mathbf{b} B_{3}$, dense lamellae type pyrope. The micro-FTIR spectrum of subgroup $B_{3}$ shows the $\mathrm{OH}$ bands in exsolved amphibole at near 3685 and $3710 \mathrm{~cm}^{-1}$

pargasite occurred at such relatively low-pressure conditions.

The importance of minor amounts of $\mathrm{Na}$ and $\mathrm{OH}$ in garnet as UHP indicators has been suggested in previous studies (e.g., Irifune et al. 1989; Bell and Rossman 1992a). The first report on Na-rich garnet is from a majoritic garnet with $1.08 \mathrm{wt} \% \mathrm{Na}_{2} \mathrm{O}$ that occurs as an inclusion in kimberlitic diamond (Moore and Gurney 1985). At present, reports on observed occurrences of Na-rich garnet are limited to UHP metamorphic rocks and inclusions in diamond from kimberlite pipes (Sobolev and Lavrent'ev 1971; Bishop et al. 1978; Enami et al. 1995; Song et al. 2005).
Previous UHP experiments have demonstrated that $\mathrm{Na}$ can be incorporated in garnet structures together with other elements such as excess $\mathrm{Si}, \mathrm{Ti}$, and $\mathrm{P}$ at UHP conditions to form $\mathrm{Na}-\mathrm{Si}\left(\mathrm{Na}_{2} \mathrm{MgSi}_{5} \mathrm{O}_{12}\right.$; see Gasparik 1989 and Bobrov et al. 2008), $\mathrm{Na}-\mathrm{Ti}\left(\mathrm{Na}_{2} \mathrm{CaTi}_{2} \mathrm{Si}_{3} \mathrm{O}_{12}\right.$; see Ringwood and Lovering 1970), and $\mathrm{Na}-\mathrm{P}\left(\mathrm{Na}_{3} \mathrm{Al}_{2} \mathrm{P}_{3} \mathrm{O}_{12}\right.$; see Brunet et al. 2006) components of garnet. Hydrous Na-garnet, $\left(\mathrm{Mg}, \mathrm{Ca}, \mathrm{Na}_{\mathrm{x}}\right)_{3}\left(\mathrm{Al}_{2-\mathrm{x}}, \mathrm{Mg}_{\mathrm{x}}\right)_{2} \mathrm{Si}_{3} \mathrm{O}_{12-2 \mathrm{x}}(\mathrm{OH})_{2 \mathrm{x}}$, described as precursor composition in this paper has not been identified in UHP experiments as of yet and is a solid solution with a previously unidentified $\mathrm{Na}$ bearing hydrous endmember of the garnet group at UHP conditions. 


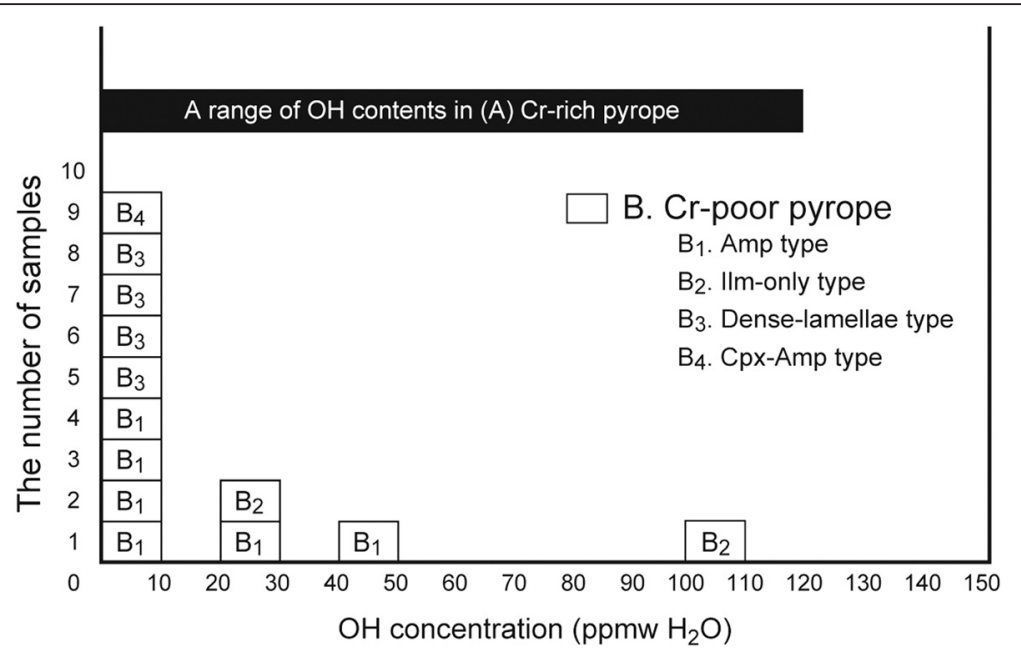

Fig. $8 \mathrm{OH}$ contents determined by micro-FTIR absorption in pyrope from Garnet Ridge

There are a few experimental studies examining stability of Na-bearing garnet. For example, Ringwood and Lovering (1970) conducted the first synthesis of Na-bearing garnet and demonstrated that the minimum pressure to synthesize Na-bearing garnet $\left(1.2 \mathrm{wt} \% \mathrm{Na}_{2} \mathrm{O}\right.$ ) from a mixture of clinopyroxene and ilmenite (2:3) is approximately $105 \mathrm{~kb}$ at $1000{ }^{\circ} \mathrm{C}$. In UHP experiments conducted by Gasparik (1989), Na-rich majorite garnet was synthesized at $133 \mathrm{kbar}$ and $1650{ }^{\circ} \mathrm{C}$ with the composition $\mathrm{En}_{42} \mathrm{Di}_{9} \mathrm{Jd}_{49}$; for pyroxene with starting compositions with $\mathrm{Jd}<60 \mathrm{~mol} \%$; pressures in excess of $140 \mathrm{kbar}\left(\right.$ at $1500{ }^{\circ} \mathrm{C}$ ) were required to form garnet with Na-bearing pyroxene compositions. In UHP experiments in the $\mathrm{Mg}_{3} \mathrm{Al}_{2} \mathrm{Si}_{3} \mathrm{O}_{12}$ $\mathrm{Na}_{2} \mathrm{MgSi}_{5} \mathrm{O}_{12}$ system conducted by Bobrov et al. (2008), Na-rich garnet with 1.52 wt\% $\mathrm{Na}_{2} \mathrm{O}\left(6 \mathrm{~mol} \% \mathrm{Na}_{2} \mathrm{Mg}\right.$ $\mathrm{Si}_{5} \mathrm{O}_{12}$ ) was synthesized at $8.5 \mathrm{GPa}$ and $1760{ }^{\circ} \mathrm{C}$ and demonstrated that $\mathrm{Na}$ concentrations in garnet increase with increasing pressure or with decreasing temperature. Since direct experimental data on hydrous Na-garnet are lacking, its stability limit is unclear. Considering the experimentally determined conditions of anhydrous Na-bearing garnet and the natural occurrence of Na-rich garnets in UHP settings, we conclude that hydrous Na-garnet must be stable at least in UHP conditions.

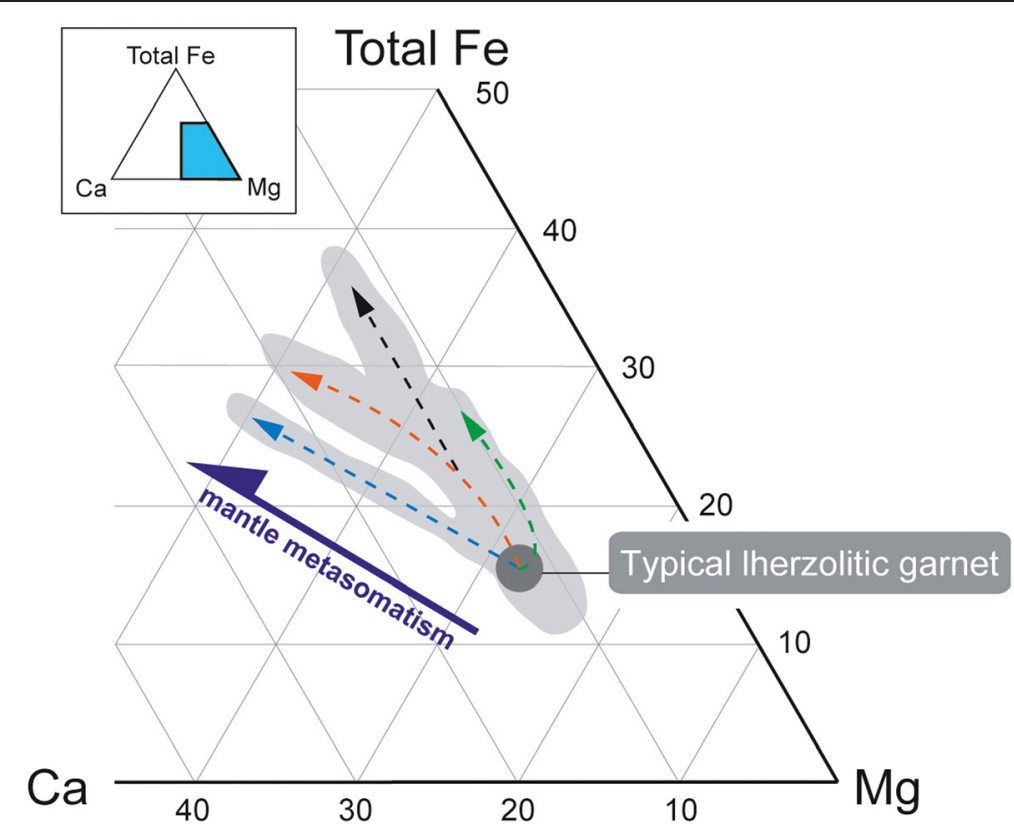

Fig. 9 A schematic model of modification of garnet chemistry during metasomatic processes at mantle depths. The dark-gray spot shows the representative chemical composition of group A, Cr-rich pyrope, the protolith of mantle metasomatism. The lighter gray area shows chemical compositions of group B: Cr-poor pyrope. Colored arrows indicate trends of chemical changes of group B garnet during mantle metasomatism 
We estimated growth conditions of hydrous $\mathrm{Na}$-garnet from subgroup $\mathrm{B}_{4}$, clinopyroxene and amphibole lamellae type, in which exsolved amphibole coexists with exsolved Na-bearing clinopyroxene (up to 5.3 wt\% $\mathrm{Na}_{2} \mathrm{O}$ ). The presence of $\mathrm{Na}$-bearing pyroxene exsolution lamellae suggests that precursor garnet had excess $\mathrm{Si}$ as a characteristic of majorite garnet under UHP conditions (e.g., Moore and Gurney 1985; Van Roermund et al. 2001). The coexistence of exsolved amphibole and clinopyroxene in single garnet grains indicates that $\mathrm{Na}-, \mathrm{OH}-$, and $\mathrm{Si}$-rich components were dissolved in the precursor garnet. As a first step toward estimating growth conditions of the garnet, we recalculated an original excess Si component of garnet based on modes and compositions of clinopyroxene lamellae and surrounding garnet host in a representative domain of $\mathrm{B}_{4}$ garnet. The modes were estimated from $1000 \mu \mathrm{m} \times 1000 \mu \mathrm{m}$ elemental maps. The mode of clinopyroxene lamella in this area reaches $1.7 \%$, resulting in a calculated excess $\mathrm{Si}$ content of 0.017 apfu (based on 12 oxygen). For garnet with excess $\mathrm{Si}$, charge balance can be maintained by paired substitution of divalent cations $\left(\mathrm{M}^{2+}\right)$, such as $\mathrm{Mg}$, for trivalent $\mathrm{Al}$ in the six-coordinated site of garnet structure (Ringwood 1967); thus, the $\mathrm{B}_{4}$ garnet described above probably had a six-coordinated site consisting of $\mathrm{M}_{0.017}^{2+} \mathrm{Al}_{1.966} \mathrm{Si}_{0.017}$ apfu (12 oxygen basis) prior to exsolution of clinopyroxene. Gasparik (1990) conducted experiments in the system, $\mathrm{CaO}-\mathrm{MgO}-\mathrm{Al}_{2} \mathrm{O}_{3}-\mathrm{SiO}_{2}$, and demonstrated that $\mathrm{Al}$ contents in garnet decrease with increasing pressure due to formation of majoritic garnet. According to his results, the garnet with $\mathrm{Al}_{1.966}$ apfu is stable at pressures of $8 \mathrm{GPa}$ at $1000{ }^{\circ} \mathrm{C}, 7 \mathrm{GPa}$ at $1200{ }^{\circ} \mathrm{C}$, and $6 \mathrm{GPa}$ at $1400{ }^{\circ} \mathrm{C}$. These results suggest that our hydrous $\mathrm{Na}$-garnet formed in a depth range of 200-250 km, suggesting origin in asthenospheric mantle (Condie 2005; O'Reilly and Griffin 2006).

Trace amounts of $\mathrm{OH}$ are identified in garnet from kimberlitic xenoliths/xenocrysts and UHP metamorphic rocks; (1) 2-163 ppmw in mantle-delivered pyrope (Matsyuk et al. 1998); (2) 92 to 1735 ppmw in eclogitic garnet from Dabieshan (Xia et al. 2005); and (3) up to ca. $1500 \mathrm{ppmw}$ in the Kokchetav garnetclinopyroxene rocks (Sakamaki et al. 2014). Importance of garnet as an $\mathrm{OH}$ reservoir in the upper mantle should not be ignored. A few UHP experiments demonstrated that $\mathrm{OH}$ solubilities in garnet were controlled by pressure conditions; $\mathrm{Lu}$ and Keppler (1997) ascertained that $\mathrm{OH}$ solubility in pyrope increases with pressure <10 GPa from $73.5 \mathrm{ppmw}$ (at $15 \mathrm{kbar}$, $1000{ }^{\circ} \mathrm{C}$ ) to $198.9 \mathrm{ppmw}$ (at $100 \mathrm{kbar}, 1000{ }^{\circ} \mathrm{C}$ ). Withers et al. (1998) showed that $\mathrm{OH}$ solubility in pyrope increase with pressure $<6 \mathrm{GPa}$ from $140 \mathrm{ppmw}$ (at $20 \mathrm{kbar}, 1000{ }^{\circ} \mathrm{C}$ ) to $960 \mathrm{ppmw}$ (at $60 \mathrm{kbar}, 1000{ }^{\circ} \mathrm{C}$ ) but then decreases to 0 ppmw until $13 \mathrm{GPa}$; their results are different from those of $\mathrm{Lu}$ and Keppler
(1997) at pressures $>7 \mathrm{GPa}$. In either case, $\mathrm{OH}$ solubility in pyrope increases with pressure up to $6 \mathrm{GPa}$.

In this study, the $\mathrm{OH}$ contents in group $\mathrm{A}$ garnet range from below the detection limit ( $<1 \mathrm{ppmw})$ to $115 \mathrm{ppmw}$. Such $\mathrm{OH}$ contents in group A garnet are typical of $\mathrm{OH}$ contents in mantle-delivered pyrope; for example, less than 2 ppmw up to 163 ppmw in mantle pyrope from kimberlite pipes of the Siberian platform (Matsyuk et al. 1998) and less than 1 ppmw up to 135 ppmw in subcontinental lithosphere delivered garnet from 18 kimberlite pipes in southern Africa (Bell and Rossman 1992b). In contrast, exsolved amphibole-bearing garnet, subgroups $\mathrm{B}_{1}$ (3-42 ppmw), $\mathrm{B}_{3}(4-10 \mathrm{ppmw})$, and $\mathrm{B}_{4}$ (2 ppmw), have significantly lower $\mathrm{H}_{2} \mathrm{O}$ contents than those in the lherzolitic or websteritic garnet of group A (up to $115 \mathrm{ppmw}$ ) and the exsolved amphibole-free subgroup $\mathrm{B}_{2}$ (27 and 101 ppmw). The lower $\mathrm{H}_{2} \mathrm{O}$ contents in amphibole-bearing garnets are interpreted as a consequence of transfer of $\mathrm{OH}$ from host garnet to amphibole during exsolution.

\section{Growth conditions of hydrous Na-garnet}

$\mathrm{Na}$ is considered to be a minor element in the upper mantle; Na contents in average mantle peridotite (pyrolite) were estimated as no higher than 0.4 wt $\% \mathrm{Na}_{2} \mathrm{O}$ by Ringwood (1975). Bishop et al. (1978) describe garnetlherzolite xenoliths in African kimberlites containing $\mathrm{Na}$-poor (0.017-0.038 wt\% $\left.\mathrm{Na}_{2} \mathrm{O}\right)$ garnet coexisting with Na-rich clinopyroxene (2.01-4.66 wt $\% \mathrm{Na}_{2} \mathrm{O}$ ), Na-poor orthopyroxene (0.053-0.181 wt $\left.\% \mathrm{Na}_{2} \mathrm{O}\right)$, and $\mathrm{Na}$-poor olivine (0-0.013 wt\% $\left.\mathrm{Na}_{2} \mathrm{O}\right)$. The results of Bishop et al. (1978) suggest that most of $\mathrm{Na}$ is partitioned into clinopyroxene rather than garnet at upper mantle conditions. It is likely that the absence of clinopyroxene is one of the keys for growth of Na-rich garnet. Among our hydrous Na-garnet (subgroups $B_{1}, B_{3}$, and $B_{4}$ ), subgroup $\mathrm{B}_{4}$ garnet apparently formed without coexisting with clinopyroxene (see Table 1). In contrast, for subgroups $B_{1}$ and $B_{3}$, the occurrence of trapped inclusions of clinopyroxene in garnet (Table 1) indicates that clinopyroxene was present during garnet growth. The second key for growth of Na-rich garnet is perhaps locally high concentration of $\mathrm{Na}$ in the upper mantle; subgroups $\mathrm{B}_{1}$ and $\mathrm{B}_{3}$ garnet likely formed under Na-concentrated environments at upper mantle depths.

Growth conditions of hydrous Na-garnet are considered dependent on the following conditions: (1) 200-250 km depth, in asthenospheric mantle; (2) pyroxenitic host rocks; (3) volatile-rich metasomatic environments; and (4) Na-enriched environments. The linear variations in $\mathrm{Mg}-\mathrm{Fe}-\mathrm{Ca}$ contents (Fig. 9) suggest that initial, pre-metasomatic garnets had $\mathrm{Mg}$-rich compositions typical of lherzolitic garnet. We infer that hydrous $\mathrm{Na}$-garnet formed in pyroxenites that 
are products of metasomatism of typical mantle lherzolites/westerites by infiltration of Na-rich aqueous fluids. The most likely sources of Na-rich aqueous fluids are oceanic plates subducted into the upper mantle, because $\mathrm{Na}$ contents in oceanic crust (2-3 wt\% $\mathrm{Na}_{2} \mathrm{O}$; Sun et al. 1979) are much higher than those in typical mantle pyrolite (0.4 wt\% $\mathrm{Na}_{2} \mathrm{O}$; Shido et al. 1971). During ocean-floor metamorphism when crust is produced at oceanic ridges, the oceanic crust and sublithospheric mantle of oceanic plates are typically enriched with water. Water contents increase from $<1 \mathrm{wt} \% \mathrm{H}_{2} \mathrm{O}$ in primitive oceanic crust (Poli and Schmidt 1995) to up to ca. $5 \mathrm{wt} \% \mathrm{H}_{2} \mathrm{O}$ in hydrated oceanic crust (Peacock 1993). During subduction, this hydrated, Na-enriched oceanic crust is transported to the upper mantle, providing a source material for the formation of hydrous Na-garnet at upper mantle conditions (e.g., Katayama et al. 2006).

Hydrous subducted oceanic plates are eventually dehydrated by breakdown of hydrous phases such as serpentine, lawsonite, amphiboles, and micas, and as a result, $\mathrm{H}_{2} \mathrm{O}$-rich fluids are released in the deep upper mantle (e.g., Poli and Schmidt 1995). Significant amounts of $\mathrm{Na}$ are likely dissolved to aqueous fluids released from hydrous subducted oceanic plates. Such Na-rich aqueous fluids could ascend to overlying mantle peridotites and cause metasomatism of primitive mantle lherzolite and websterite (the host rock of group A garnet in this study) at depths $>200 \mathrm{~km}$. During mantle metasomatism, typical lherzolite and websterite may transform to pyroxenites. Hydrous Na-garnet probably forms in such metasomatized pyroxenites under Na-rich aqueous fluids environments.

Until at least $30 \mathrm{Ma}$ when kimberlitic volcanism occurred at Garnet Ridge (Smith et al. 2004), the oceanic Farallon plate subducted beneath the west coast of North America and apparently extended at a shallow subduction angle to the mantle region below the Colorado Plateau (Coney and Reynolds 1977; Bunge and Grand 2000). Is the Farallon Plate the source of Na-rich aqueous fluids that caused mantle metasomatism of peridotites underneath the Colorado Plateau? According to the petrologic and geochronologic work of Usui et al. (2003), just before eruption of kimberlite $30 \mathrm{Ma}$, oceanic crust of the Farallon Plate existed at depths of $100-150 \mathrm{~km}\left(3-5 \mathrm{GPa} ; 560-700{ }^{\circ} \mathrm{C}\right)$. Even if the Farallon Plate was dehydrated underneath the Colorado Plateau, Na-rich aqueous fluids released from the Farallon Plate probably ascended to overlying shallow mantle (Schulze et al. 2015). In such shallow mantle conditions $(<100 \mathrm{~km})$, pargasite is a more stable hydrous Na-bearing phase than hydrous Na-garnet (Green 1973). Consequently, we suggest that dehydration of the Farallon Plate is not the origin of Na-rich aqueous fluid to form hydrous $\mathrm{Na}$-garnet.
Instead, the hydrous Na-garnet may have grown in the asthenospheric mantle underneath the Farallon Plate. According to estimated growth conditions of subgroup $\mathrm{B}_{4}$ garnet at least $6 \mathrm{GPa}, 1200{ }^{\circ} \mathrm{C}$ to $8 \mathrm{GPa}, 1000{ }^{\circ} \mathrm{C}$, the hydrous Na-garnet must have grown at depths $>200 \mathrm{~km}$, probably in asthenospheric mantle A possible source of Na-rich aqueous fluids causing mantle metasomatism in asthenospheric mantle is ancient deeply subducted oceanic crust before subduction of the Farallon Plate.

$\mathrm{Na}$ and $\mathrm{OH}$ in pyrope garnet from the Colorado Plateau indicate not only UHP conditions of upper mantle origin, but also have important implications for the history of mantle metasomatism related to mantle dynamics, such as plume tectonics and subduction of oceanic plates underneath the North American Plate. Future research on direct age dating and trace components in pyrope garnets from the Navajo Volcanic Field will be necessary for deciphering the origin of the Na-rich hydrous garnets and their relation to the geologic history of formation of the Colorado Plateau.

\section{Conclusions}

Pyrope xenocrysts from Garnet Ridge are classified into two groups: group A, Cr-rich pyrope; and group B, $\mathrm{Cr}$-poor pyrope. The group $\mathrm{B}$ is subdivided into four subgroups: $B_{1}$ amphibole lamella type; $B_{2}$ ilmenite lamella only type; $\mathrm{B}_{3}$ dense lamellae type; and $\mathrm{B}_{4}$ clinopyroxeneamphibole lamellae type. Exsolved amphibole occurs in $\mathrm{B}_{1}, \mathrm{~B}_{3}$, and $\mathrm{B}_{4}$ as monomineralic prisms/tablets and as multimineralic needles/blades with other exsolved phases such as rutile, ilmenite, srilankite, apatite, and clinopyroxene. Exsolved amphibole mainly has pargasitic compositions.

$\mathrm{OH}$ contents in exsolved amphibole-bearing garnet host (subgroups $\mathrm{B}_{1}, \mathrm{~B}_{3}$, and $\mathrm{B}_{4}$ ) are significantly lower than those of exsolved amphibole-free garnet (group $A$ and subgroup $\mathrm{B}_{2}$ ). This suggests a loss of $\mathrm{OH}$ in garnet host during amphibole exsolution.

Amphibole exsolution in pyrope crystals resulted from breakdown of hydrous Na-garnet components in precursor garnet at $<3 \mathrm{GPa}$ during decompression. Hydrous Na-garnet was apparently formed by metasomatism of mantle peridotite caused by infiltration of Na-rich fluids in asthenospheric mantle (at least 200-250 km) under the Colorado Plateau. Metasomatic Na-rich fluids probably originated from dehydration of ancient oceanic crust that was subducted before subduction of the Farallon Plate.

Competing interests

The authors declare that they have no competing interests. 


\section{Authors' contributions}

KS and YS proposed the topic and conceived and designed the study. YS analyzed the Raman data. KS analyzed the micro-FTIR data. KS and YS carried out the EMP analysis. All authors discussed the results and their interpretation. All authors read the final manuscript and $Y O$ gave final approval of the manuscript to be submitted.

\section{Acknowledgements}

The authors thank Ms. P. Deswudt and her family, who collected all of the samples used in this study and sold the samples to us. The authors thank Dr. T. Morishita of Kanazawa University and an anonymous reviewer for their perceptive reviews of this article. We also thank Dr. TJ. Fagan for his valuable comments and improving the English of this manuscript. This work was supported by JSPS KAKENHI Grant Numbers 15204050, 15J07628 and Waseda University Grant no. 2006A-038.

Received: 13 January 2016 Accepted: 29 May 2016

Published online: 11 July 2016

\section{References}

Aines RD, Rossman GR (1984) The hydrous component in garnets: pyralspites. Am Mineral 69:1116-1126

Bell DR, Rossman GR (1992a) Water in earth's mantle: the role of nominally anhydrous minerals. Science 255:1391-1397. doi:10.1126/science.255.5050. 1391

Bell DR, Rossman GR (1992b) The distribution of hydroxyl in garnets from the subcontinental mantle of southern Africa. Contrib Mineral Petrol 111:161-178. doi:10.1007/BF00348949

Bishop FC, Smith JV, Dawson JB (1978) Na, K, P and Ti in garnet, pyroxene and olivine from peridotite and eclogite xenoliths from African kimberlites. Lithos 11:155-173. doi:10.1038/35012586

Bobrov AV, Litvin YA, Bindi L, Dymshits AM (2008) Phase relations and formation of sodium-rich majoritic garnet in the system $\mathrm{Mg}_{3} \mathrm{Al}_{2} \mathrm{Si}_{3} \mathrm{O}_{12}-\mathrm{Na}_{2} \mathrm{MgSi}_{5} \mathrm{O}_{12}$ at 7.0 and 8.5 GPa. Contrib to Mineral Petrol 156:243-257. doi:10.1007/s00410008-0283-3

Brunet $F$, Bonneau V, lrifune T (2006) Complete solid-solution between $\mathrm{Na}_{3} \mathrm{Al}_{2}\left(\mathrm{PO}_{4}\right)_{3}$ and $\mathrm{Mg}_{3} \mathrm{Al}_{2}\left(\mathrm{SiO}_{4}\right)_{3}$ garnets at high pressure. Am Mineral 91:211-215. doi:10. 2138/am.2006.2053

Bunge HP, Grand SP (2000) Mesozoic plate-motion history below the northeast Pacific Ocean from seismic images of the subducted Farallon slab. Nature 405:337-340. doi:10.1038/35012586

Condie KC (2005) TTGs and adakites: are they both slab melts? Lithos 80:33-44. doi:10.1016/j.lithos.2003.11.001

Coney PJ, Reynolds SJ (1977) Cordilleran benioff zones. Nature 270:403-406. doi: 10.1038/275464a0

Danchin RV, Wyatt BA (1979) Statistical cluster analysis of garnets from kimberlites and their xenoliths. Kimberlite Symposium II., pp 22-27

Dawson JB, Stephens WE (1975) Statistical classification of garnets from kimberlite and associated xenoliths. J Geol 83:589-607. doi:10.1086/628143

Deer WA, Howie RA, Zussman J (eds) (1992) An introduction to the rock-forming minerals (second edition). Pearson Prentice Hall, London

Enami M, Cong B, Yoshida T, Kawabe I (1995) A mechanism for Na incorporation in garnet: an example from garnet in orthogneiss from the Su-Lu terrane, eastern China. Am Mineral 80:475-482. doi:10.2138/am-1995-5-608

Gasparik T (1989) Transformation of enstatite-diopside-jadeite pyroxenes to garnet. Contrib to Mineral Petrol 102:389-405. doi:10.1007/BF00371083

Gasparik T (1990) Phase relations in the transition zone. J Geophys Res: Solid Earth 95:15751-15769. doi:10.1029/JB095iB10p15751

Green DH (1973) Experimental melting studies on a model upper mantle composition at high pressure under water-saturated and waterundersaturated conditions. Earth Planet Sci Lett 19:37-53. doi:10.1016/ 0012-821X(73)90176-3

Gregory HE (1916) Garnet deposits on the Navajo Reservation, Arizona and Utah. Eco Geol 11:223-230

Grütter HS, Gurney JJ, Menzies AH, Winter F (2004) An updated classification scheme for mantle-derived garnet, for use by diamond explorers. Lithos 77: 841-857. doi:10.1016/j.lithos.2004.04.012

Helmstaedt H, Schulze DJ (1988) Eclogite-facies ultramafic xenoliths from Colorado Plateau diatreme breccias: comparison with eclogites in crustal environments, evaluation of the subduction hypothesis, and implications for eclogite xenoliths from diamondiferous kimberlites. In: Smith DJ (ed)
Eclogites and Eclogite-Facies Rocks. Developments in Petrology, vol 12 Elsevier, Amsterdam, pp 387-450

Irifune T, Hibberson WA, Ringwood AE (1989) In: Ross J (ed) Eclogite-garnetite transformation at high pressure and its bearing on the occurrence of garnet inclusions in diamond in Kimberlites and Related Rocks. Blackwell, Melbourne

Katayama I, Nakashima S, Yurimoto H (2006) Water content in natural eclogite and implication for water transport into the deep upper mantle. Lithos 86: 245-259. doi:10.1016/j.lithos.2005.06.006

Leake BE, Woolley AR, Arps CES, Birch WD, Gilbert MC, Grice JD, Hawthorne FC, Kato A, Kisch HJ, Krivovichev VG, Linthout K, Laird J, Mandarino JA, Maresch W, Nickel EH, Rock NMS, Schumacher JC, Smith DC, Stephenson NCN, Ungaretti L, Whittaker JW, Youzhi G (1997) Nomenclature of amphiboles: report of the subcommittee on amphiboles of the international mineralogical association, commission on new minerals and minerals names. Can Mineral 35:219-246

Libowitzky E, Rossman GR (1997) An IR absorption calibration for water in minerals. Am Mineral 82:1111-1115. doi:10.2138/am-1997-11-1208

Lu R, Keppler H (1997) Water solubility in pyrope to $100 \mathrm{kbar}$. Contrib to Mineral Petrol 129:35-42. doi:10.1007/s004100050321

Matsyuk SS, Langer K, Hösch A (1998) Hydroxyl defects in garnets from mantle xenoliths in kimberlites of the Siberian platform. Contrib to Mineral Petrol 132:163-179. doi:10.1007/s004100050414

Mookherjee M, Karato S (2010) Solubility of water in pyrope-rich garnet at high pressures and temperature. Geophys Res Lett 37. doi:10.1029/ 2009GL041289.

Moore RO, Gurney JJ (1985) Pyroxene solid solution in garnets included in diamond. Nature 318:553-555. doi:10.1029/2009GL041289

Ogasawara Y, Sakamaki K, Koga I (2012) Hydroxyl in garnets from Garnet Ridge, northern Arizona. AGU Fall Meeting 2012 abstract., pp V43A-2821

Ogasawara Y, Sakamaki K, Sato Y (2013) Water contents of garnets from the Garnet Ridge, northern Arizona: $\mathrm{H}_{2} \mathrm{O}$ behavior underneath the Colorado Plateau. AGU Fall Meeting 2013 abstract., pp V23A-2754

O'Reilly SY, Griffin WL (2006) Imaging global chemical and thermal heterogeneity in the subcontinental lithospheric mantle with garnets and xenoliths: Geophysical implications. Tectonophysics 416:289-309. doi:10.1016/j.tecto. 2005.11.014

Peacock SM (1993) The importance of blueschist $\rightarrow$ eclogite dehydration reactions in subducting oceanic crust. Geol Soc Am Bull 105:684-694. doi:10. 1130/0016-7606(1993)105<0684:TIOBED>2.3.CO;2

Poli S, Schmidt MW (1995) H2O transport and release in subduction zones: experimental constraints on basaltic and andesitic systems. J Geophys Res 100:299-314. doi:10.1029/95JB01570

Ringwood AE (1967) The pyroxene-garnet transformation in the earth's mantle. Earth Planet Sci Lett 2:255-263. doi:10.1016/0012-821X(67)90138-0

Ringwood AE (1975) Composition and petrology of the Earth's mantle. McGrawHill, New York

Ringwood AE, Lovering JF (1970) Significance of pyroxene-ilmenite intergrowths among kimberlite xenoliths. Earth Planet Sci Lett 7:371-375. doi:10.1016/ 0012-821X(69)90052-1

Roden MF, Smith D, McDowell FW (1979) Age and extent of potassic volcanism on the Colorado Plateau. Earth Planet Sci Lett 43:279-284. doi:10.1016/0012$821 \times(79) 90212-7$

Sakamaki K, Ogasawara Y, Schertl HP (2014) OH and $\mathrm{H}_{2} \mathrm{O}$ distributions in garnet of diamond-free and diamond-bearing garnet-clinopyroxene rocks from the Kokchetav Massif. AGU Fall Meeting 2014 abstract., pp V13B-4775

Sapienza GT, Scambelluri M, Braga R (2009) Dolomite-bearing orogenic garnet peridotites witness fluid-mediated carbon recycling in a mantle wedge (Ulten Zone, Eastern Alps, Italy). Contrib to Mineral Petrol 158:401-420. doi: 10.1007/s00410-009-0389-2

Sato Y, Ogasawara Y (2013) Inclusion/lamella mineralogy and chemical characteristics of garnets from the Garnet Ridge in the Colorado Plateau, northern Arizona. AGU Fall Meeting 2013 abstract., pp V23A-2756

Sato Y, Koga I, Ogasawara Y (2014) Major element chemistry and inclusion/ lamella mineralogy of garnets from the Garnet Ridge in the Colorado Plateau, northern Arizona. AGU Fall Meeting 2014 abstract., pp V13B-4777

Sautter V, Haggerty SE, Field S (1991) Ultradeep (>300 kilometers) ultramafic xenoliths: petrological evidence from the transition zone. Science 252:827830. doi:10.1126/science.252.5007.827

Schulze DJ (2003) A classification scheme for mantle-derived garnets in kimberlite: a tool for investigating the mantle and exploring for diamonds. Lithos 71:195-213. doi:10.1016/S0024-4937(03)00113-0 
Schulze DJ, Davis DW, Helmstaedt H, Joy B (2015) Timing of the Cenozoic "Great Hydration" event beneath the Colorado Plateau: Th-Pb dating of monazite in Navajo volcanic field metamorphic eclogite xenoliths. Geology 43:727-730. doi:10.1130/G36932.1

Semken S (2003) Black rocks protruding up: the Navajo volcanic field. Geology of the Zuni Plateau: New Mexico. Geol Soc Guidebook 54:397-412

Shido F, Miyashiro A, Ewing M (1971) Crystallization of abyssal tholeiites. Contrib to Mineral Petrol 31:251-266. doi:10.1007/BF00374440

Smith D, Connelly JN, Manser K, Moser DE, Housh TB, McDowell FW, Mack LE (2004) Evolution of Navajo eclogites and hydration of the mantle wedge below the Colorado Plateau, southwestern United States. Geochem Geophys Geosyst 5:1-18. doi:10.1029/2003GC000675

Sobolev NV Jr, Lavrent'ev JG (1971) Isomorphic sodium admixture in garnets formed at high pressures. Contrib to Mineral Petrol 31:1-12. doi:10.1007/ BF00373387

Song S, Zhang L, Liou JG, Niu Y (2005) Sodic amphibole exsolutions in garnet from garnet-peridotite, North Qaidam UHPM belt, NW China: implications for ultradeep-origin and hydroxyl defects in mantle garnets. Am Mineral 90:814-820. doi:10.2138/am.2005.1684

Sun SS, Nesbitt RW, Sharaskin AY (1979) Geochemical characteristics of midocean ridge basalts. Earth Planet Sci Lett 44:119-138. doi:10.1016/0012821X(79)90013-X

Switzer GS (1975) Composition of garnet xenocrysts from three kimberlite pipes in Arizona and New Mexico. Smithsonian Earth Sci 19:-21

Usui T, Nakamura E, Kobayashi K, Maruyama S, Helmstaedt H (2003) Fate of the subducted Farallon plate inferred from eclogite xenoliths in the Colorado Plateau. Geology 31:589-592. doi:10.1130/0091-7613(2003)031<0589: FOTSFP>2.0.CO;2

Usui T, Nakamura E, Helmstaedt H (2006) Petrology and geochemistry of eclogite xenoliths from the Colorado Plateau: implications for the evolution of subducted oceanic crust. J Petrol 47:929-964. doi:10.1093/petrology/egi101

Usui T, Kobayashi K, Nakamura E, Helmstaedt H (2007) Trace element fractionation in deep subduction zones inferred from a lawsonite-eclogite xenolith from the Colorado Plateau. Chem Geol 239:336-351. doi:10.1016/j. chemgeo.2006.08.009

Van Roermund HLM, Drury MR, Barnhoorn A, De Ronde A (2001) Relict majoritic garnet microstructures from ultra-deep orogenic peridotites in western Norway. J Petrol 42:117-130. doi:10.1093/petrology/42.1.117

Vrijmoed JC, Austrheim H, John T, Hin RC, Corfu F, Davies GR (2013) Metasomatism in the ultrahigh-pressure Svartberget garnet-peridotite (western gneiss region, Norway): implications for the transport of crust-derived fluids within the mantle. J Petrol 54:1815-1848. doi:10.1093/petrology/egt032

Wang L, Essene EJ, Zhang Y (1999) Mineral inclusions in pyrope crystals from Garnet Ridge, Arizona, USA: implications for processes in the upper mantle. Contrib to Mineral Petrol 135:164-178. doi:10.1007/s004100050504

Wang L, Rouse RC, Essene EJ, Peacor DR (2000) Carmichaelite, a new hydroxylbearing titanate from Garnet Ridge, Arizona. Am Mineral 85:792-800. doi:10 2138/am-2000-5-620

Watson KD, Morton DM (1969) Eclogite inclusions in kimberlite pipes at Garnet Ridge, northeastern Arizona. Am Mineral 54:267-285

Withers AC, Wood BJ, Carroll MR (1998) The OH content of pyrope at high pressure. Chem Geol 147:161-171. doi:10.1016/S0009-2541(97)00179-4

Xia QK, Sheng YM, Yang XZ, Yu HM (2005) Heterogeneity of water in garnets from UHP eclogites, eastern Dabieshan, China. Chem Geol 224:237-246. doi: 10.1016/j.chemgeo.2005.08.003

\section{Submit your manuscript to a SpringerOpen ${ }^{\circ}$ journal and benefit from:}

- Convenient online submission

- Rigorous peer review

- Immediate publication on acceptance

- Open access: articles freely available online

- High visibility within the field

- Retaining the copyright to your article

Submit your next manuscript at $\boldsymbol{\nabla}$ springeropen.com 